\title{
Stratigraphic implications of the Mio-Pliocene geodynamics in the area of Mt. Avala: new evidence from Torlak Hill and Beli Potok (Belgrade, Serbia)
}

\author{
Ljupko Rundić*, Meri Ganić, Slobodan Knežević, Dejan Radivojević and Miloš Radonjić
}

University of Belgrade, Faculty of Mining and Geology, Department of Regional Geology, Kamenička 6, 11000 Belgrade, Serbia; (corresponding author: ljupko.rundic@rgf.bg.ac.rs)

doi: $10.4154 / g c .2019 .11$

Article history:

Manuscript received February 22, 2018 Revised manuscript accepted February 28, 2019 Available online June 3, 2019

Keywords: Mio-Pliocene geodynamics, Southern Pannonian Basin, Avala and Torlak horsts, Beli Potok trough, Serbia

\begin{abstract}
Mt. Avala is located on the southern margin of the Pannonian basin (SPB), a border zone between the uplifted morphostructures of the Dinarides and Carpathian-Balkanides. Similar to the Pannonian basin, tectonostratigraphic evolution of the Mt. Avala area during the last $23 \mathrm{Ma}$ has is characterized by syn- and post-rifting processes as well as tectonic inversion. Here, we present the results of field investigations of the Miocene-Pliocene dynamics that led to different spatial positions of the same stratigraphic units (e.g. Badenian and Pannonian) in a relatively small area. These spatial relationships are interpreted in the context of pronounced block structures (Torlak, Beli Potok and Avala). Torlak Hill represents a horst structure with a core composed of Mesozoic rocks and hillsides composed of the Middle Miocene sediments, which are present at the surface at altitudes up to 336 metres. Nearby, there is the Beli Potok asymmetrical trough that was infilled by the late Miocene sediments. The Torlak horst and the Beli Potok trough structures are separated by the Rakovica normal fault. In some places along the fault line, several geological units are vertically displaced more than a hundred metres. For example, in borehole KGK-14, the Upper Miocene Pannonian marls are observed at a depth of 100 metres below the surface. However, only a few hundred metres away to the northeast, similar Pannonian marls are observed at the surface, at an altitude of about 210 metres. Due to the mentioned observed vertical movements along the block structures, a composite hilly relief with dominant the Torlak Hill and the Beli Potok Valley was formed.
\end{abstract}

\section{INTRODUCTION}

Since the early pioneering work of e.g. ROYDEN et al. (1983) and HORVÁTH (1984), the following thirty years or so have seen publication of a lot of papers concerning the origin and evolution of the Pannonian Basin (PB) and its marginal parts e.g. TARI \& PAMIĆ (1998); BADA et al. (1999); HORVÁTH et al. (2006); DOMBRÁDI (2012); KOVÁCS et al. (2015); BALÁZS et al. (2017 and references therein). Generally, in these papers a very complex interdisciplinary and multidisciplinary approach has been applied. Although, some of the authors didn’t have similar views to the general model of the PB and mechanisms of its genesis, longterm investigations led to greater understanding of these processes. Today, the general structural pattern concerning the evolution of the PB is accepted (e.g. MATENCO \& RADIVOJEVIĆ, 2012; BALÁZS et al., 2016, 2017 and references therein). It is evident that the Early to Middle Miocene pre- and syn-rift deposits of the PB show a transition from continental alluvial-lacustrine to fully marine environments (PAVELIĆ \& KOVAČIĆ, 1999; HARZHAUSER \& PILLER, 2007; HARZHAUSER \& MANDIC, 2008; MAGYAR et al., 2013; SANT et al., 2017). The peak of extensional tectonics was reached during the Badenian-Sarmatian rifting phase (ca. 16-12 Ma) (e.g. FODOR et al., 2005; RADIVOJEVIĆ et al., 2010; MATENCO \& RADIVOJEVIĆ, 2012; RADIVOJEVIĆ \& RUNDIĆ, 2016). The long-lived Lake Pannon was formed at the Middle/Late Miocene boundary (ca. 11.6 Ma) as a consequence of the tectonic uplift of the Carpathians that separated the basin from marine influences (MAGYAR et al., 1999; TER BORGH et al., 2013, 2015; SZTANÓ et al.,
2015). Seven million years later, Lake Pannon was filled with lacustrine and fluvio-deltaic sediments derived from the surrounding orogenic belts (e.g. MAGYAR et al., 2013; RADIVOJEVIĆ \& RUNDIĆ, 2016). At the beginning of the Pliocene, the "caspibrackish" giant Lake Pannon was reduced to the much smaller freshwater Paludina Lake (MAGYAR et al., 1999; SZTANÓ et al., 2015; MANDIC et al., 2015; RUNDIĆ et al., 2016). A similar scenario was demonstrated from the southern margin of the Pannonian Basin (RUNDIĆ et al., 2011, 2015, 2017).

At the beginning of the Miocene, the studied area was represented by continental-lacustrine facies of different ages (DOLIĆ, 1997, 1998; KRSTIĆ et al., 2012; RUNDIĆ et al., 2013, 2015). During the Middle Miocene (Badenian), a maximum extension led to Paratethys marine flooding in Serbia as well as in other countries at the southern margin of the PB (e.g. ĆORIĆ et al., 2009; KOVAČIĆ et al., 2011; PAVELIĆ \& KOVAČIĆ, 2018; SANT et al., 2018). The Late Middle Miocene to Pliocene postrift thermal stage of subsidence was weak but more extensive than during the Badenian (MAROVIĆ et al., 1995; 2002; 2007; RADIVOJEVIĆ \& RUNDIĆ, 2016). At the end of the Miocene, Mt. Avala was an elongate island, with lake-margin and swamp environments formed along its shoreline. Later, the PlioceneQuaternary tectonic compression reactivated some older faults and the Lake Pannon sediments were differentially displaced and lost their lateral continuity (e.g. MAROVIĆ \& KNEŽEVIĆ, 1985; KNEŽEVIĆ, 1989; MAROVIĆ et al., 1995; 2002; 2007; TOLJIĆ et al., 2014). Consequently, the system of uplifted block structures 


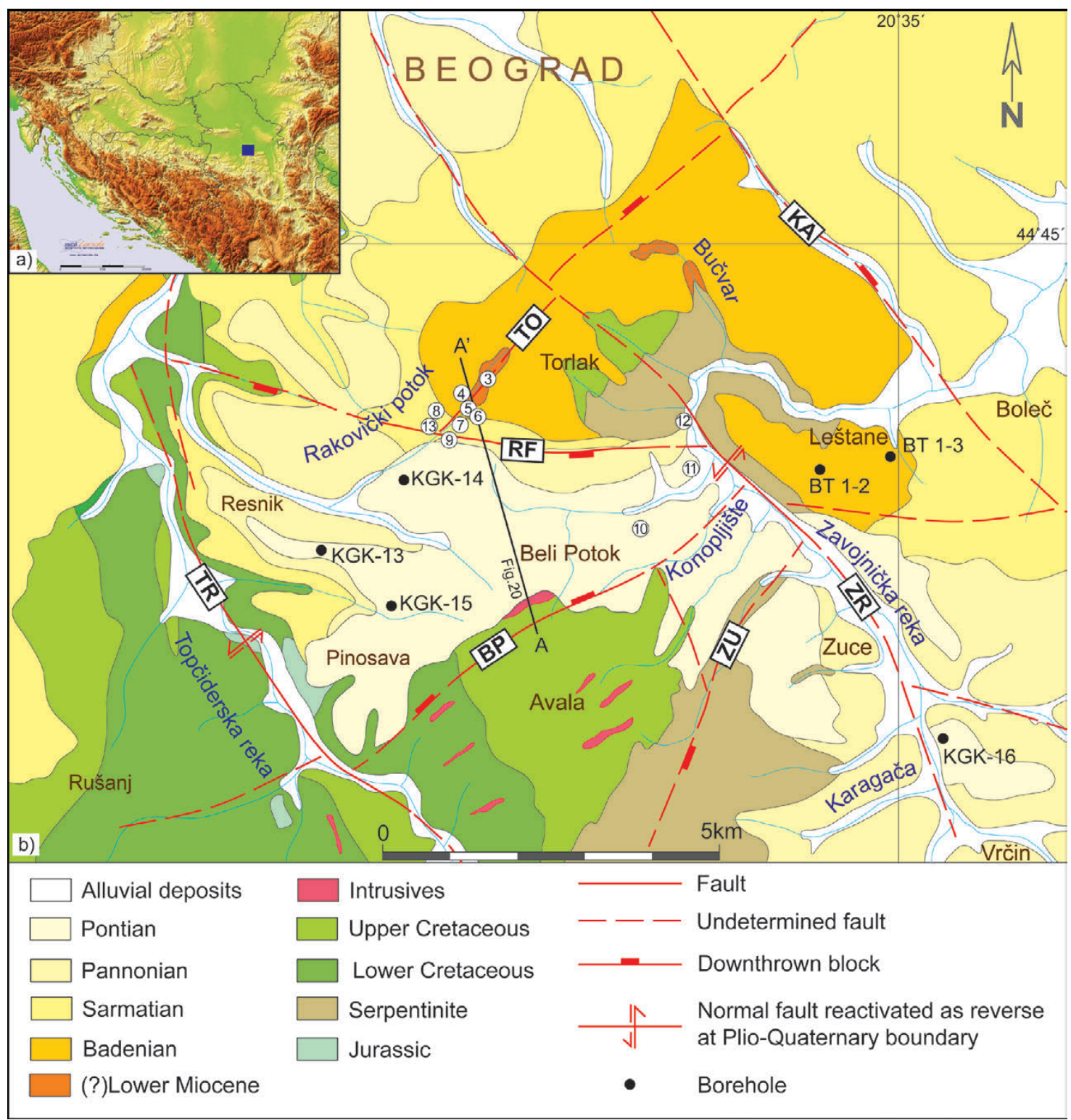

Figure 1. Location (a) and geological sketch map (b) of the studied area (modified and upgraded after IVKOVIĆ et al., 1966 and TOLIĆ, 2016). Numbers mark the studied outcrops and figure numbers in the text. Key: TO - Torlak fault; RF - Rakovica fault; TR - Topčiderska reka fault; BP - Beli Potok fault; ZR - Zavojnička reka fault; ZU - Zuce fault, KA - Kaludjerica fault. Note: Traces of the aforementioned faults are taken from MAROVIĆ et al. 2007).

with Lake Pannonian deposits were exposed to erosion and weathering processes.

In this study, the research objective was to provide more insights about the evolution of this relatively small-scale area (Fig. 1). Starting from the distribution of Miocene sediments in the field, their exposure in the relief and an interesting relationship between the geological units (normal or tectonic boundaries, erosional contact, unconformity, spatial position of same units, etc.) we collected principal biostratigraphic, structural and geomorphologic evidence to show the distinct effects of Mio-Pliocene tectonics especially its stratigraphic implications.

\section{GEOLOGICAL SETTINGS}

The studied area is located on the southern margin of the PB, a border zone between the uplifted morphostructures of the Dinarides and the Carpathian-Balkanides (MAROVIĆ \& KNEŽEVIĆ, 1985; ANDJELKOVIĆ \& ANDJELKOVIĆ 1996). According to the regional tectonic setting of Serbia, the older Mesozoic units in this area belong to the Tethys oceanic domain, i.e. the Vardar zone in the wider sense (DIMITRIJEVIĆ, 1997; TOLJIĆ, 2006, 2016) and the Sava zone (SCHMID et al., 2008).

The study area represents a region with complex geological features and is composed of various igneous and sedimentary rocks formed during the Mesozoic, Tertiary and Quaternary periods (MAROVIĆ et al., 1995, 2002, 2007; TOLJIĆ, 1996; 2006, 2016; GANIĆ et al., 2011).The oldest rocks belong to Jurassic carbonates, ophiolitic mélange, serpentinized peridotites, Lower and Upper Cretaceous carbonates and Upper Cretaceous turbiditic and flysch deposits (TOLJIĆ, 2016; TOLJIĆ et al., 2018). During the Oligocene, magmatic bodies forming dykes and sills of different thickness were intruded into these rocks (VASKOVIĆ \& MATOVIĆ, 1996; TOLJIĆ et al., 2018). All these rocks represent the basement rocks in the area. Much later, different Miocene and Quaternary sedimentary units unconformably overlie Jurassic serpentinites or Cretaceous sediments (Fig. 2). Older Miocene units (?Lower Miocene continental-lacustrine formation, predominantly) have a relatively narrow distribution 


\begin{tabular}{|c|c|c|c|c|c|c|c|}
\hline \multicolumn{3}{|c|}{ AGE } & $\mathrm{m}$ & LITHOLOGY & BIO-AND LITHOFACIES & \multicolumn{2}{|c|}{ GEODYNAMICS } \\
\hline $\begin{array}{l}\frac{1}{10} \\
\frac{1}{2} \\
\frac{1}{1} \\
\frac{1}{0} \\
\frac{1}{0} \\
0\end{array}$ & $\begin{array}{l}\frac{1}{2} \\
\frac{2}{0} \\
\frac{2}{D}\end{array}$ & 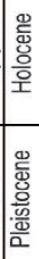 & \begin{tabular}{|l|} 
유 \\
\\
$\stackrel{ }{\sim}$ \\
\end{tabular} & 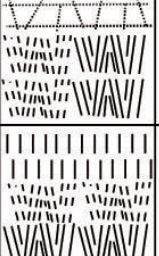 & $\begin{array}{l}\text { Alluvial, colluvial, deluvial and } \\
\text { proluvial sediments }\end{array}$ & \multirow{2}{*}{ 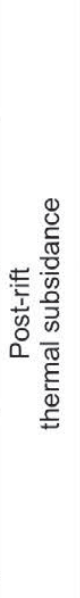 } & Inversion \\
\hline 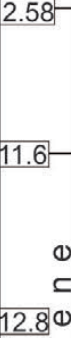 & $\begin{array}{l}\frac{1}{ \pm} \\
\text { 응 } \\
\frac{2}{\supset}\end{array}$ & 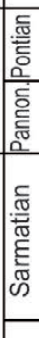 & ํำ & 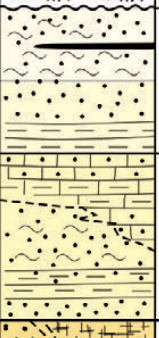 & $\begin{array}{l}\text { Biogenic sandy limestone, marl, } \\
\text { sandstone, sand and clay } \\
\text { (Marine to brackish Paratethys) }\end{array}$ & & Uplifting \\
\hline$\frac{0}{\Sigma}$ & $\frac{\varrho}{\frac{0}{\partial}}$ & 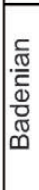 & $\stackrel{0}{0}$ & 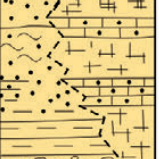 & $\begin{array}{l}\text { Reef, biogenic limestone, marl, } \\
\text { sandy marl, sand, silt, clay and } \\
\text { conglomerate } \\
\text { (Marine Paratethys) }\end{array}$ & \multirow{2}{*}{ 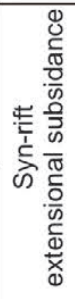 } & Rift climax \\
\hline & \multicolumn{2}{|c|}{ 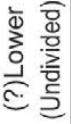 } & 응 & 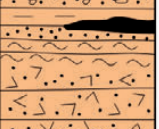 & $\begin{array}{l}\text { Marl, silt, clay, tuffite, } \\
\text { coal interlayer } \\
\text { (Continental/lacustrine pre-marine) }\end{array}$ & & Initial rifting \\
\hline \multicolumn{3}{|c|}{$\begin{array}{l}\text { Upper } \\
\text { Cretaceous }\end{array}$} & ○ & 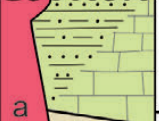 & $\begin{array}{l}\text { Shallow water carbonates, } \\
\text { Avala Flysch } \\
\text { Andesite (a) }\end{array}$ & \multirow{2}{*}{\multicolumn{2}{|c|}{$\begin{array}{l}\text { Closure of Tethys } \\
\text { Ocean }\end{array}$}} \\
\hline Jure & ssic & & 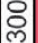 & & Serpentinite & & \\
\hline
\end{tabular}

Figure 2. Schematic geological column of the pre-Neogene basement rocks and Neogene-Quaternary succession with palaeoenvironments and tectonic stages of the studied area (modified after IVKOVIĆ et al., 1966 and GANIĆ et al. 2016).

(DOLIĆ, 1997; RUNDIĆ et al., 2013). Middle Miocene marine and marine-brackish sediments are well developed and have been extensively studied (e.g. LUKOVIĆ, 1922; STEVANOVIĆ, 1951; EREMIJA, 1977a, 1987; PETROVIĆ, 1995; KNEŽEVIĆ \& ŠUMAR, 1994; RUNDIĆ \& KNEŽEVIĆ, 2017). Similarly, the late Miocene „,caspibrackish“ sediments of the Lake Pannon were the subject of various stratigraphic studies beginning with the well-known studies by PAVLOVIĆ (1931) and STEVANOVIĆ (1951), followed by the biostratigraphic articles of KRSTIĆ (1972, 1973, 1985), STEVANOVIĆ $(1985,1990)$, EREMIJA (1989) and KNEŽEVIĆ (1989).

\section{MATERIALS AND METHODS}

Most of the rock samples have been collected from both banks of the Rakovica Stream valley (Rakovički potok) located in the N-NW part of Mt. Avala. Other samples have been taken more toward the north-northeast of Mt. Avala (Torlak, Beli Potok, Leštane, and Vrčin - Fig. 1). All the analyzed samples were collected from the twelve outcrops and sections and two shallow boreholes (Fig. 1). Primarily, they were used for palaeontological and biostratigraphic analyses. Fossil macrofauna (mostly molluscs) as well as their biostratigraphic position has been used for determining the different Miocene units. After cleaning and preparation with water and hydrogen-peroxide, some of the specimens were subsequently examined under reflected light by Olympus BH2 microscope. Foraminifers and ostracods were photographed by Leica binocular microscope. Some key micro- fossils were photographed using SEM (JEOL JSM6610LV) at the Department of Mineralogy and Petrology, Faculty of Mining and Geology, University of Belgrade. However, detailed analyses of these taxa are the subject of further investigations.

Bearing in mind that the area is covered by vegetation, the lack of structural information in previous research, as well as our own very poor data, the measurements of structural elements were not collected systematically (e.g. dip angle and dip direction, fault traces, geometric and kinematic properties, etc.). Scarce individual measurements of bedding plane or fault trace were performed and used to support the above-mentioned stratigraphic results with structural and geomorphologic observations in the relief. The scarce data was supplemented with the DEM terrain model and these interpretations were further connected to the previously published results. In that sense, some of ideas and conclusions could be described as provisional and are not based on real measurements in the field. Furthermore, the basic geomorphologic data (GPS coordinates and altitude, topographic map, Google Earth map, etc.) was used in order to pinpoint the main landforms and their possible relationships towards the main linear structures of relief.

\section{RESULTS}

\subsection{The studied outcrops and sections}

\subsection{1. ?Lower Miocene (Continental-lacustrine) Bučvar clastites}

In the upper portion of the Bučvar Stream (Bučvar Potok), the left tributary of the Zavojnička Reka River, i.e. Bolečica River, a 


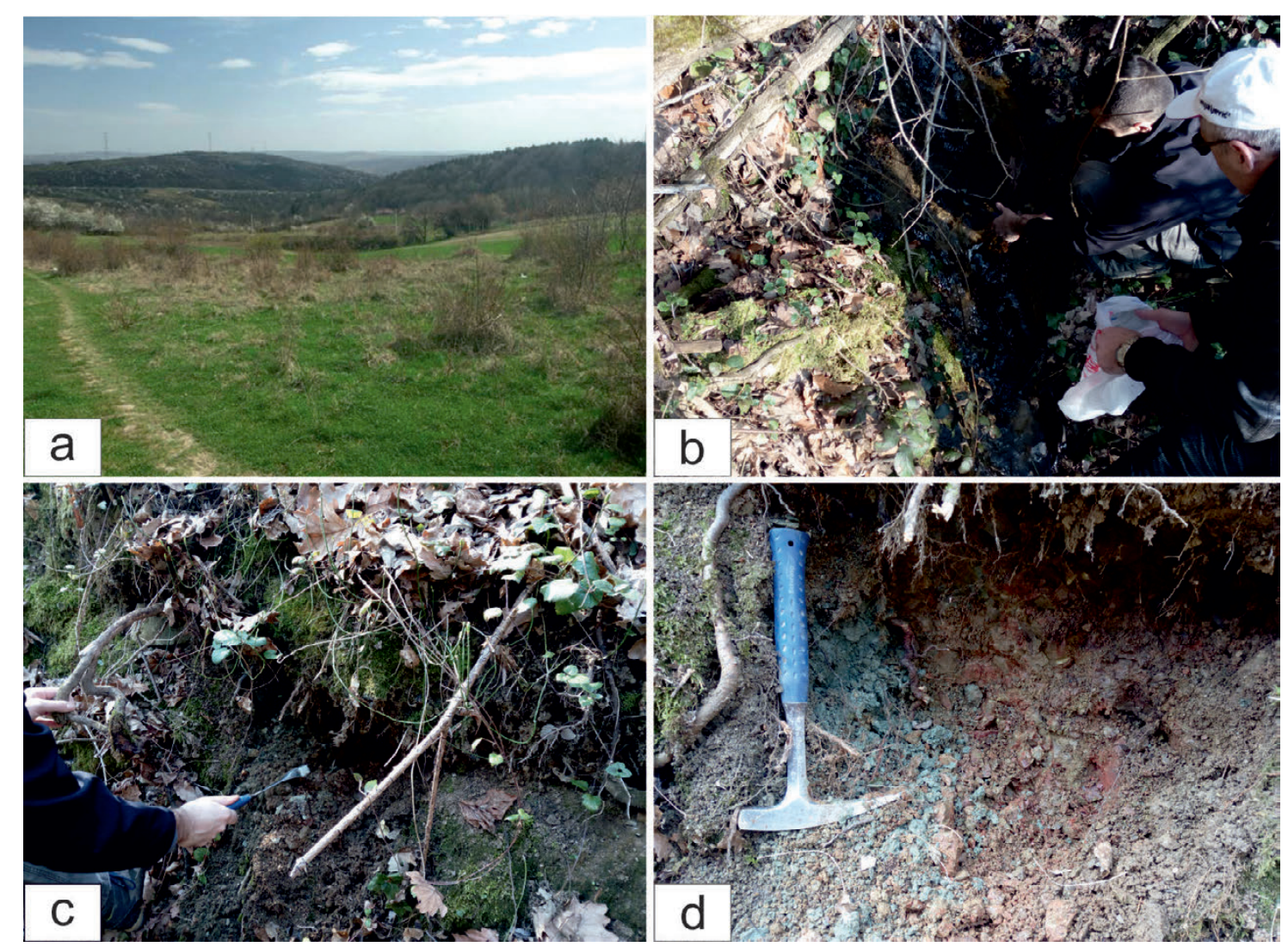

Figure 3. The continental-lacustrine ?Lower Miocene in the area of Torlak hill: Panoramic view of the Bučvar stream towards the NE (a), a view inside the stream valley (b), a detail of reddish conglomerates, light-brown coarse-grained sandstones in intercalation with green silt and clay (c, d).

thick package of clastic deposits called the Bučvar clastites

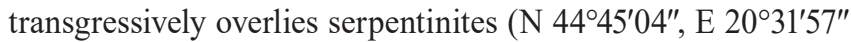
- No.3 in Fig. 1). Herein, the medium-grained conglomerates consist of serpentinite clasts, quartzites, cherts, fragments of sand, pinkish to greenish sandstones and reddish clays which together build a heterogeneous series (Fig.3b-d). Macroscopically, they are barren of fossils. STEVANOVIĆ (1970) believed that these conglomerates represent a special stratigraphic horizon at the transition from the "Helvetian to Tortonian Stage", i.e. from the Karpatian to the Badenian Stage. According to the same author, they are in tectonic contact with gray, Badenian marine clays characterized by an abundant micro- and macrofauna. STEVANOVIĆ (1970) equated those conglomerates with the youngest member of the Vrdnik Series (Fruška Gora), i.e. the Budafa conglomerates of Mecsek Mountain in southern Hungary. A similar interpretation was proposed by EREMIJA (1987). However, DOLIĆ $(1997,1998)$ is confident that the Bučvar conglomerates belong to the youngest member of the Slanci Series (?Lower Miocene, Egenburgian) and they represent the regressive phase and termination of the lacustrine environment in this area. More recent research has determined the presence of these clastites in the vicinity of Torlak Hill and in the upper part of the

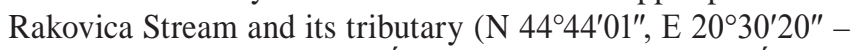
Fig.3a). According to DOLIĆ $(1997,1998)$ and RUNDIĆ et al. (2013) these clastites represent the final phase of pre-Badenian lacustrine sedimentation (Fig. 3c, d). At the same time, in this study, a similar unit was observed in boreholes BT1-2 and BT1-3 near Leštane. During exploratory drilling for the construction of the "Bubanj Potok" railway tunnel, it was observed that the Bučvar conglomerate (more than $7 \mathrm{~m}$ thick succession) transgressively overlies the serpentinite (BT1-2). They consist of reddish, brown and dark green coarser conglomerates in alternation with fine- to coarse-grained sandstones and lenses of greenish silty clay. In the field, this represents a distinct lithological succession that has a large spatial distribution and underlies the younger Miocene rocks. Unlike the overlying marine Badenian gravel, conglomerates and sands, this unit does not contain fossils and has a different colour and petrological content (DOLIĆ, 1997, 1998; RUNDIĆ et al., 2013).

\subsubsection{The Middle Miocene (Marine Badenian) Rakovica deposits}

The basal part of the Badenian marine deposits is exposed along the upper part of the Rakovica stream section and its right tributary (N 444' $59^{\prime \prime}$, E $20^{\circ} 30^{\prime} 10^{\prime \prime}$ - No.4 in Fig. 1). Nearby, the lower portion of the stream, an outcrop of coarse-grained clastic rocks composed of gravels and poorly cemented polymictic conglomerates up to $1.2 \mathrm{~m}$ high has been studied (Fig. 4a, b). The Rakovica stream deposits are composed of well-rounded and subrounded fragments of quartzites and sandstones, moderately to well-sorted essentially in the form of coarse and very coarse gravel (pebbles). Abundant platy and discoid clasts indicate an imbricated gravel (Fig. 4c) succession. However, larger clasts (cobbles) of quartzites (up to $7 \mathrm{~cm}$ ) are dominant (Fig. 4d). Besides the different rock clasts, a few indistinct remains of fossil shell imprints could be recognized (? Solecurtus sp.). Above these gravels and conglomerates, a $0.70 \mathrm{~m}$ thick yellow-brown sandstone with no visible fauna, and rare occurrences of small pebbles up to $1 \mathrm{~cm}$ diameter were observed. Stratigraphically, these rocks mark the basal part of the Badenian marine transgression in this area and transgressively overlie the previous reddish and varicoloured continental-lacustrine ?Lower Miocene sediments (DOLIĆ, 1997; RUNDIĆ et al., 2013). 

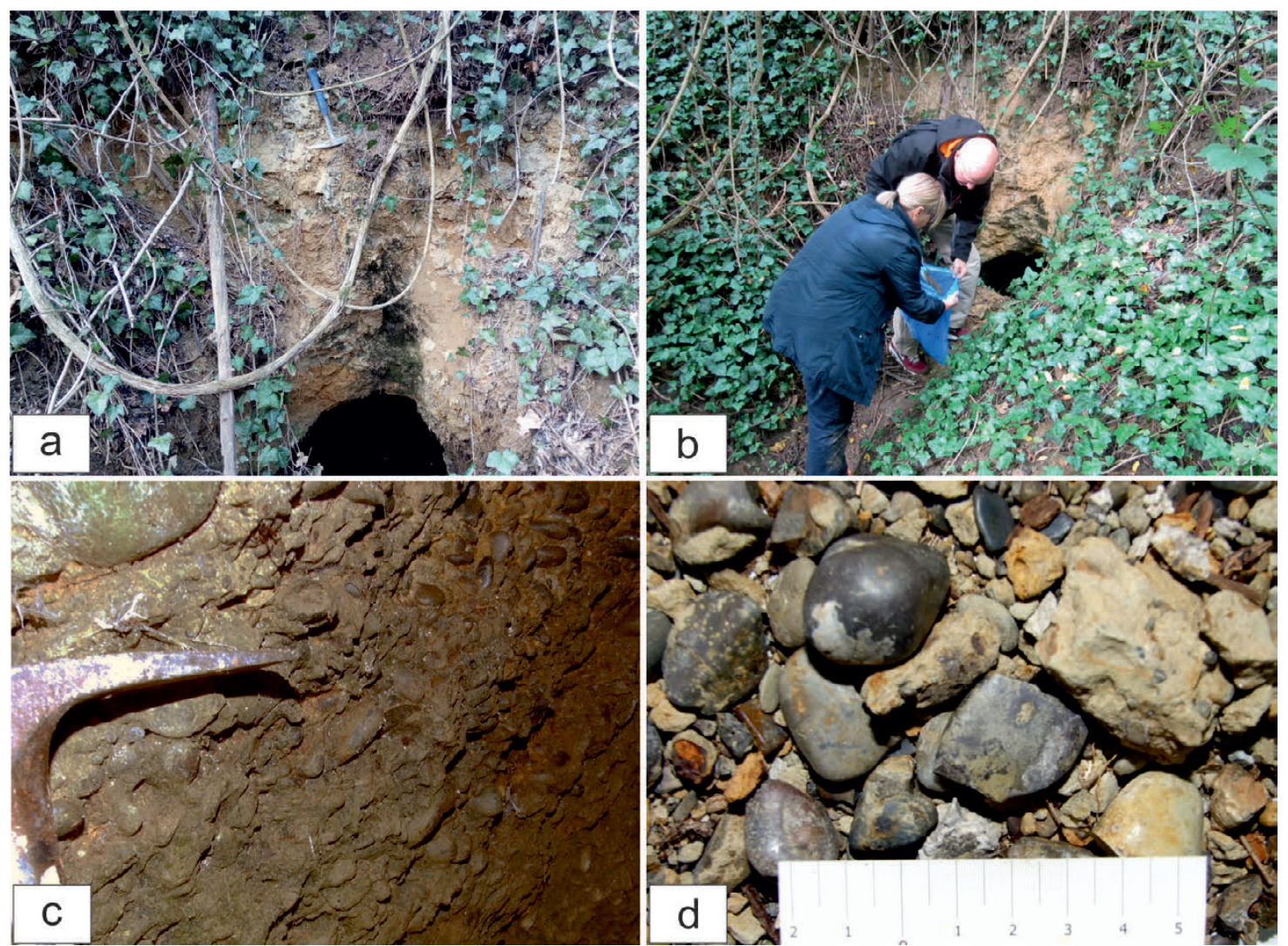

Figure 4. The Badenian basal conglomerates: Small outcrops at the upper part of the Rakovica Stream valley (a, b), a close up of the relatively well-sorted, imbricated conglomerates (c), semi-rounded pebbles of the quartzites and sandstones (d).

Above the previous outcrop, a hundred metres downstream, close to the top of the left Rakovica stream bank (Fig. 5), there is

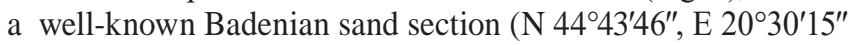
- No. 5 in Fig. 1) up to $10 \mathrm{~m}$ high. The first data concerning the "Mediterranean fauna" of the Rakovica Stream (Rakovički Potok) were described by PAVLOVIĆ $(1890,1893)$ and until recently, detailed studies about the marine Badenian shallow-water "seashore" sand were published (e.g. GANIĆ et al., 2016 and references therein). The section contains a very rich and diverse macro- and microfauna including more than 70 species of gastropods and bivalves, abundant foraminifers and ostracods, echinoids, fish otoliths, etc. that confirm the marine flooding in this area. In this study, the microfaunal association of foraminifers and ostracods (Ammonia beccarii LINNÉ, Elphidium crispum (LINNÉ), Borelis melo FICHTEL ET MOLL, Cletocythereis haidingeri (REUSS), Cnestocythere truncata (REUSS), Costa edwardsii (ROEMER) was discovered, which further addresses the depositional environment and paleoecological characteristics of the study area. The last recent detailed studies of fossil gastropods and otoliths confirm the shallow-water character of the aforementioned sands (SCHWARZHANS et al., 2015; GANIĆ et al., 2016).

A few metres higher in the succession, the ?Upper Badenian Leitha Limestone (WIEDL et al., 2012) was developed as another facies (N 444ㄴ $44^{\prime \prime}$, E 20 30'09" - No.6 in Fig. 1). It is represented by hard, poorly bedded and massive fossiliferous limestone, fractured and partly karstified at the top of the section. It appears in the form of large blocks in the relief (Fig. 6). The limestone is determined to represent a biocalcarenite. Fossil detritus is mainly composed of calcareous algae, molluscs, echinoids, bryozoans, and large benthic foraminifers. Rare detritus comprises mainly quartz clasts together with carbonates, quartzites, schists, and cherts. Clasts are well rounded and range from $0.4-1 \mathrm{~cm}$ in size. Frequent bivalve remnants (Glycymeris pilosus (LINNÉ), Flabellipecten besseri (ANDRZEJOWSKI) and Ostrea sp. are present. Gastropod (Turritella sp., Hydrobia sp., etc.), foraminifer (Amphistegina sp., Ammonia sp., Borelis sp., Textularia sp. and others), and bryozoan fragments have also been identified (GANIĆ et al., 2016). Bryozoans are represented by branching forms. According to RUNDIĆ et al. (2013) the Leitha Limestone in the study area, due to the predominant fossil composition could be categorized as an algal-foraminifer-bryozoan type of limestone.

\subsubsection{Middle Miocene (Marine-brackish Sarmatian) Rakovica deposits}

Along the Rakovica Stream valley, some two hundred metres further to the south, two new Sarmatian sections were discovered in both stream banks. The first is observed on the left bank,

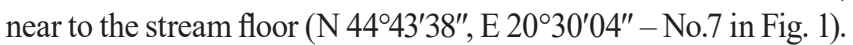
An outcrop more than $5 \mathrm{~m}$ high and up to $20 \mathrm{~m}$ long exposes grey to brownish laminated sand and poorly cemented sandstone in alternation with gray to greenish silty marl (Fig. 7a). The gentle dip angle of these sediments is variable and at the south end of the section reaches up to 13 degrees dipping towards the NE (Fig. 7b). There is no visible macrofauna. Based on the observed foraminifera and ostracod association, this section corresponds to the Lower Sarmatian deposits (Elphidium cf. reginum d'ORBIGNY, El. macellum (FICHTEL et MOLL), El. aculeatum d'ORBIGNY, Quinqueloculina sp., Ammonia ex. gr. beccarii (LINNÉ), Aurila notata (REUSS), Xestoleberis sp., etc.).

The second outcrop, is observed in a new large section ( $\mathrm{N}$ $44^{\circ} 43^{\prime} 45^{\prime \prime}$, E $20^{\circ} 29^{\prime} 54^{\prime \prime}$ - No.8 in Fig. 1) located on the opposite side 

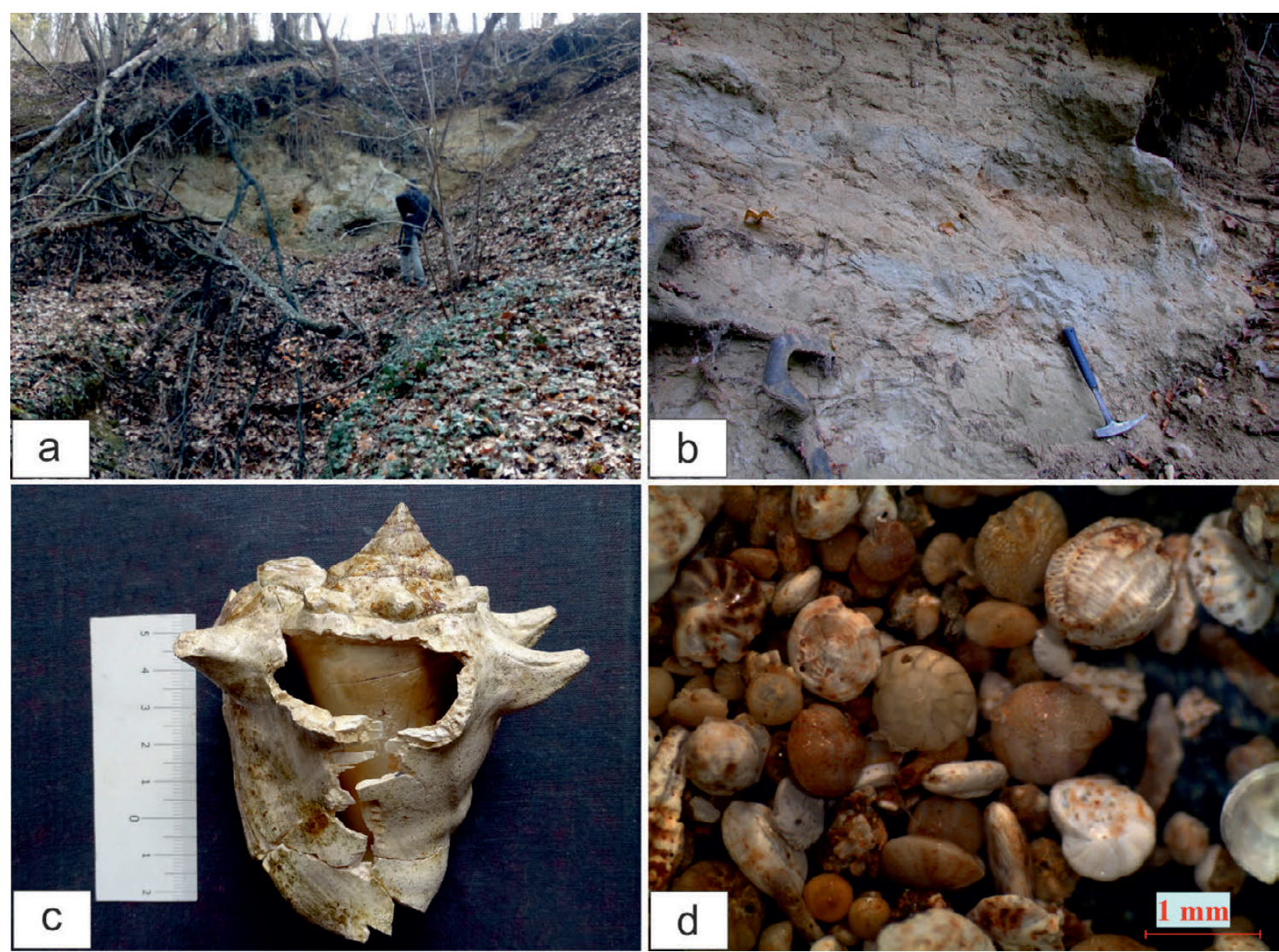

Figure 5. The Upper Badenian sands: A well-known Badenian sand section in the upper part of the Rakovica stream (a, b), Persistrombus coronatus (DEFRANCE) (c) and, typical microfossil assemblage of the Upper Badenian (Ammonia ex gr. beccarri LINNE, Elphidium crispum (LINNE), Borelis melo FICHTEL \& MOLL, etc. (d).
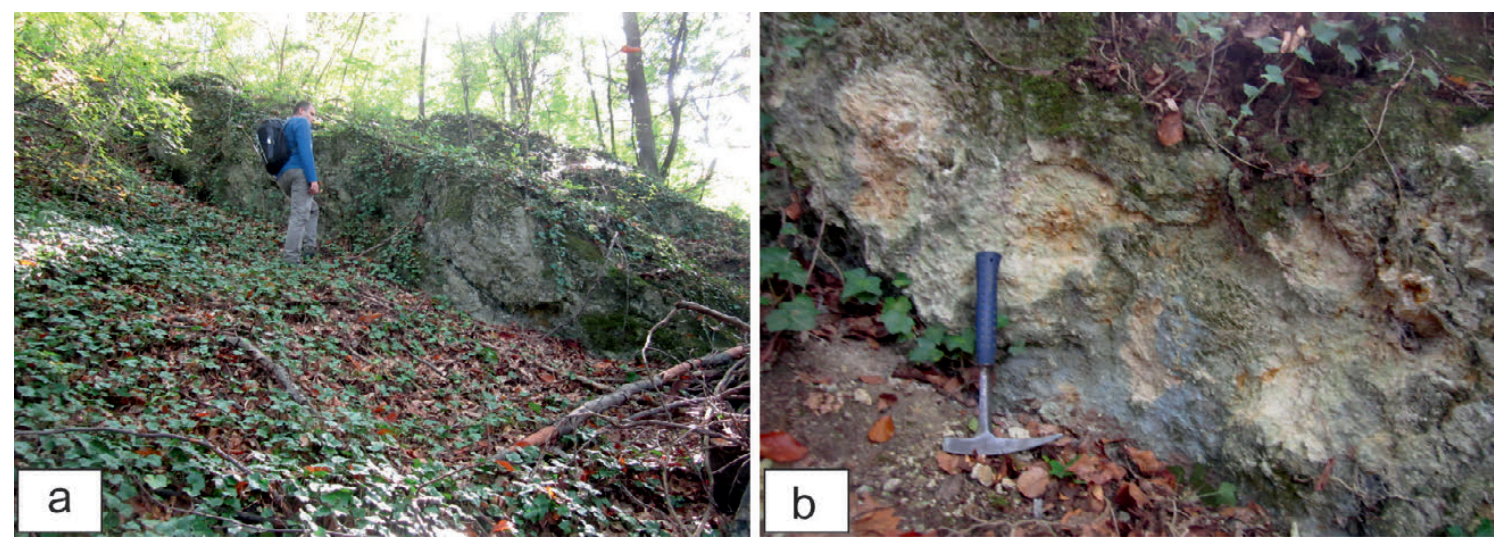

Figure 6. The Upper Badenian poorly-bedded limestone (Leitha limestone) at the upper part of the Rakovica Stream valley (a, b).
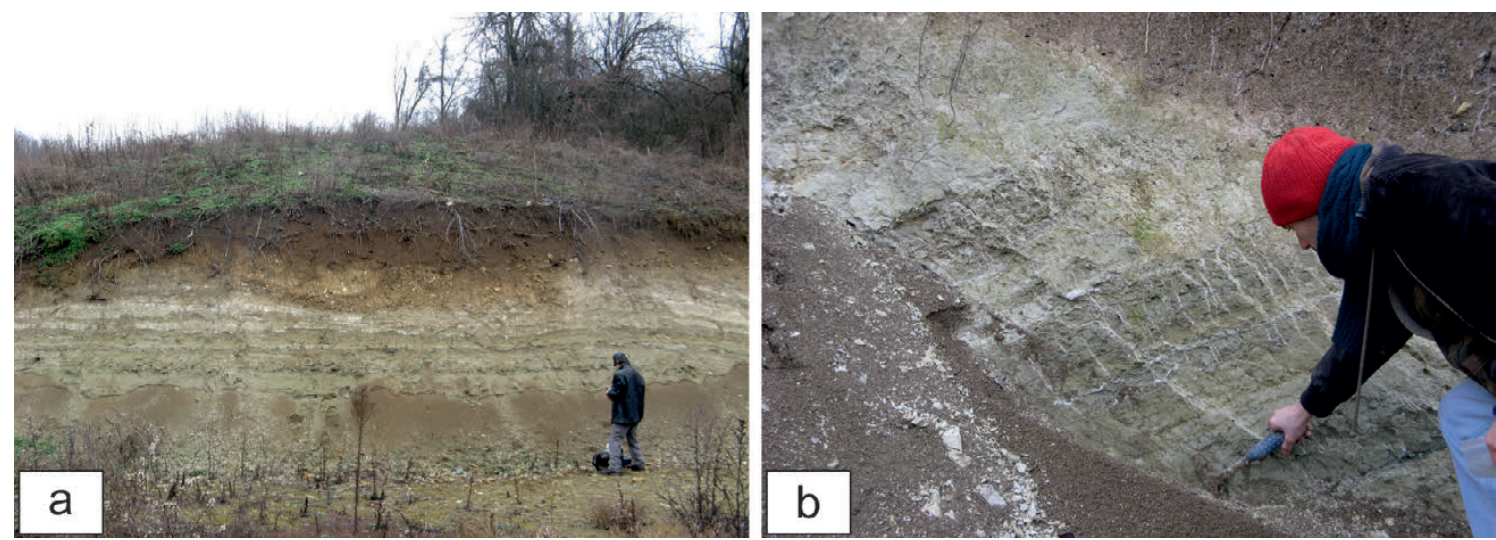

Figure 7. The Lower Sarmatian section of grey to brownish laminated sand and poorly cemented sandstone (a) in alternation with gray to greenish silty marl (b). 

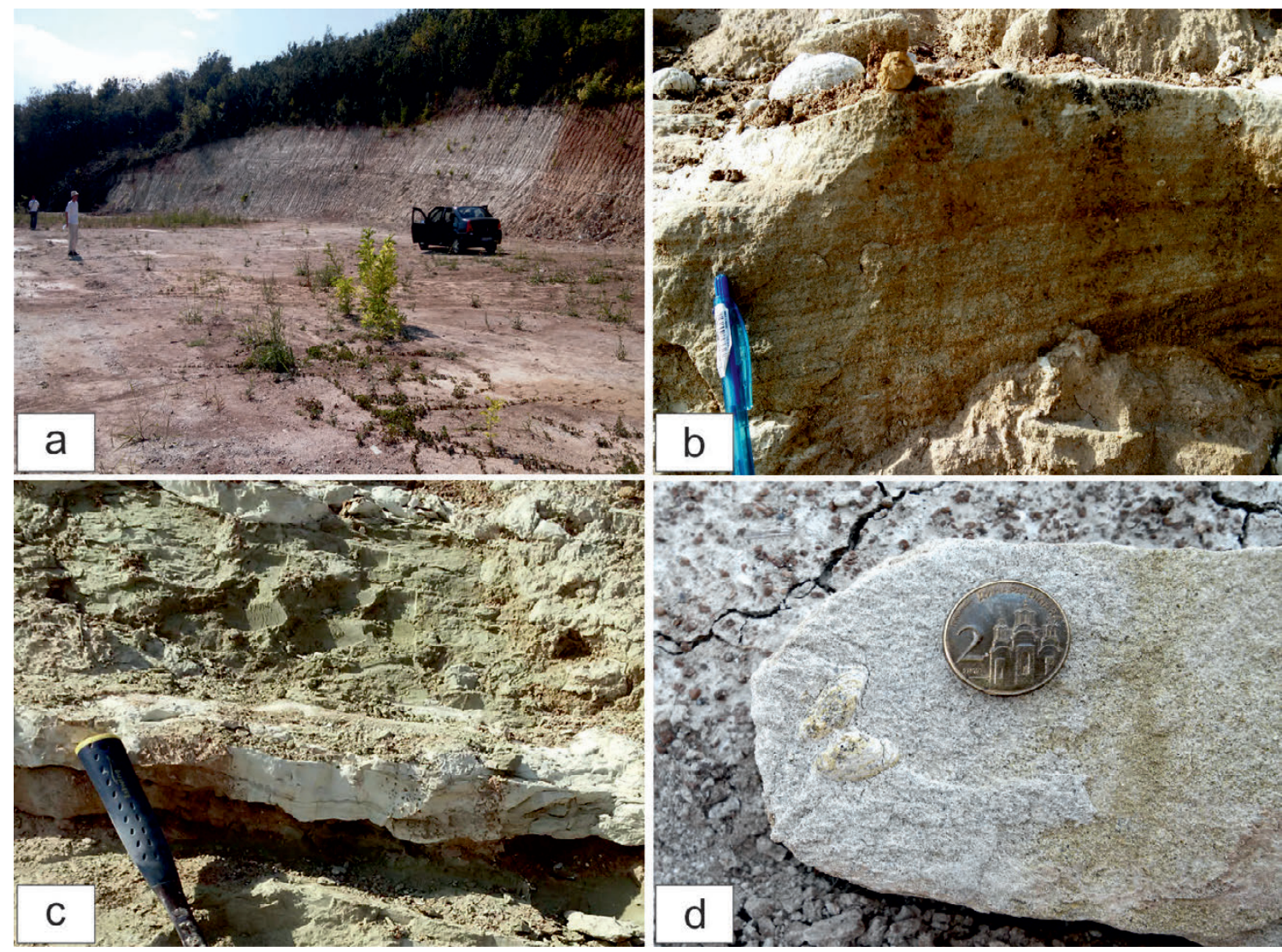

Figure 8. The Lower Sarmatian: a large section of gray, silty marl in alternation with grey to brown laminated sandstones (a, b), thin interbeds of platy limestone and marls (c) Ervilia dissita EICHWALD (d).

of the Rakovica Stream valley. It exposes a section more than $80 \mathrm{~m}$ long and up to $12 \mathrm{~m}$ high of the light brown to yellowish sands and poorly cemented parallel to cross-laminated sandstones intercalated with thin interlayers of gray marls and platy limestones (Fig. 8a-c). Stratigraphically and structurally, it overlies the previous described Sarmatian section in Fig. 7. On the westernsouthwestern part, a small lens of coarse-grained clastics and pebbles is interbedded in the lower part of the section. The mean dip angle of the sediments reaches 15 degrees (dip direction is $40^{\circ}$ ). This measured section contains relatively poor fossil association of molluscs, foraminifers and ostracods. Most of the fossils are poorly preserved and their shells are covered or partly filled by fine-grained sediments and quartz grains. Among them, the following mollusc species could be identified: Ervilia dissita Eichwald (Fig. 8d), Cerastoderma ex gr. vindobonensis (PARTSCH in
LASKAREV), ?Calliostoma sp., Cerithium sp., Pirenella sp. The following foraminifers were determined: Elphidium aculeatum (d'ORBIGNY), El. macellum (FICHTEL ET MOLL), Anomalinoides cf. dividens LUCZKOWSKA, Ammonia ex gr. beccarii (LINNÉ). Elphidiums are common within the fossil assemblage and represent the most abundant specimens. Among the ostracodes, only a few species were recognized: Heterocythereis mehesi (ZALANYI), Aurila notata (REUSS), Loxocorniculina sp. Biostratigraphically, all of the aforementioned species correspond to the Lower Sarmatian in age.

\subsubsection{Late Miocene, Lower Pannonian (= Pannonian sensu STEVANOVIĆ, 1985) Rakovica marls}

At the Rakovica Stream valley near to the Avala road, and just $200 \mathrm{~m}$ downstream of the Sarmatian section mentioned above
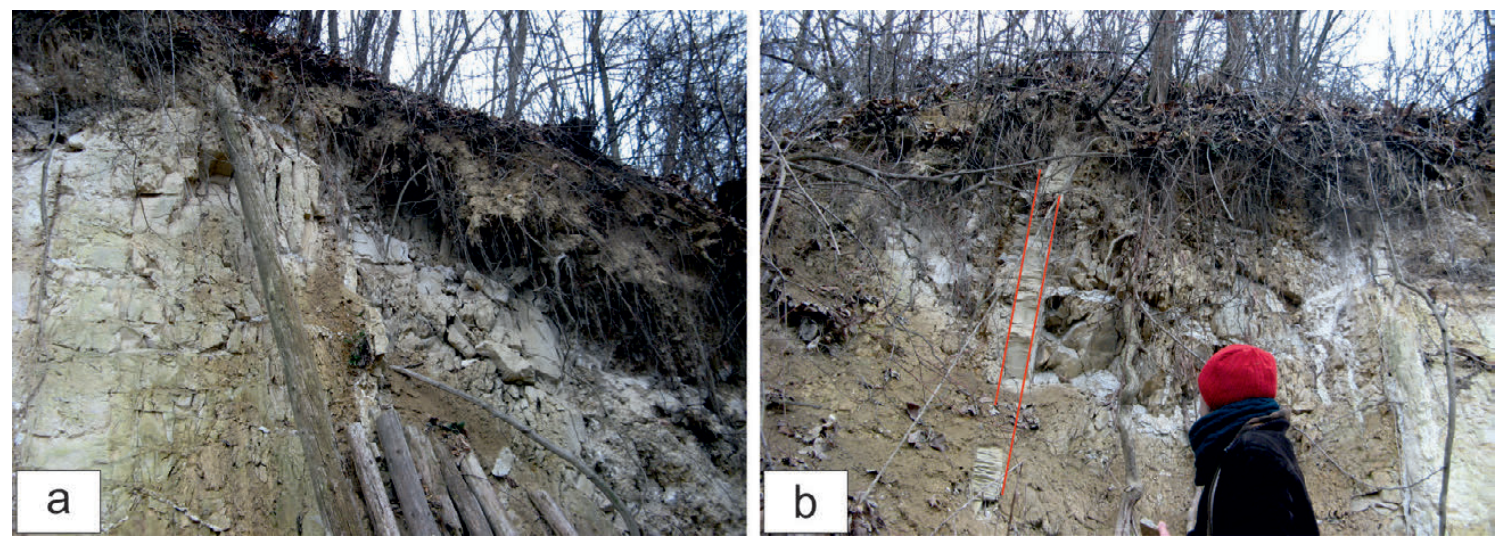

Figure 9. The Lower Pannonian sandy marl (a), sandy marls steeply dipping towards the southeast (b). 

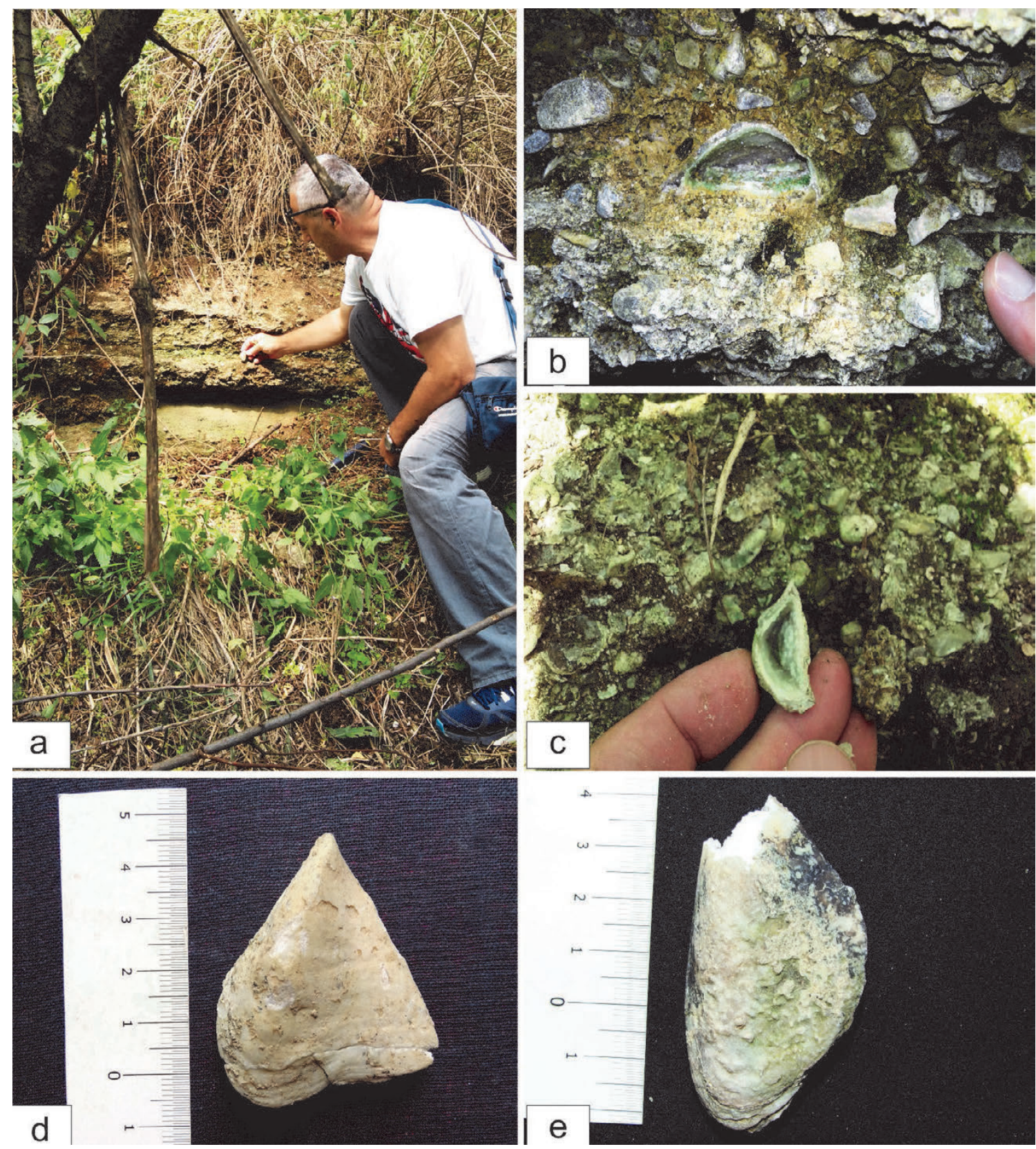

Figure 10. The Lower Pontian (sensu STEVANOVIĆ) clastics, predominantly coarse-grained gravel and semiconsolidated conglomerates (a, b), recrystallized shells of Mytilopsis sp. (c, d) and, a partly destroyed specimen of M. trnskii (BRUSINA) (e).

(Fig. 7), an outcrop of the Lower Pannonian sandy marls, several metres in height and length, was discovered ( $N 44^{\circ} 43^{\prime} 33^{\prime \prime}$, E $20^{\circ} 29^{\prime} 55^{\prime \prime}$ - No.9 in Fig. 1; Fig. 9). Rare fragments of fossil molluscs were observed (Orygoceras sp., Lymnocardium sp., Melanopsis sp.). A relatively numerous ostracod association and scarce recrystallized forms of the Sarmatian foraminifers indicates an age close to the Sarmatian/Pannonian boundary. Also, the steep dip angle of the marls $\left(73-75^{\circ}\right)$ and a dip direction to southeast suggest the deformation is related to the proximity of the Rakovica fault which is responsible for this tilting (Figs. 9b and 21). Among the ostracodes, genera such as Cyprideis, Amplocypris and Candona predominate. The following species were identified: Cyprideis kollmanni KRSTIĆ, C. cf. heterostigma (REUSS), Hemicytheria cf. folliculosa (REUSS), H. ampullata (MEHES), Candona (Propontoniella) candeo KRSTIĆ, Amplocypris cf. firmus KRSTIĆ, A. cf. recta (REUSS), A. perphoratus KRSTIĆ, Herpetocyprella auriculata (REUSS),
Cypria siboviki KRSTIĆ, Loxoconcha granifera (REUSS), L. mülleri (MEHES), L. porosa (MEHES), L. cf. rhombovalis POKORNY, Candona (Thaminocypris) improbus KRSTIĆ, Candona (Typhlocypris) lunata (MEHES), C. (T.) trigonella HEJJAS, Leptocythere(Amnicythere) miscere KRSTIĆ, L. (A) cf. servica KRSTIĆ, Loxocorniculina hodonica POKORNY, Xestolebris sp.

\subsubsection{Late Miocene, Upper Pannonian (= Pontian sensu STEVANOVIĆ, 1985) Beli Potok clastic deposits}

Along the road to the Konopljište stream, in the Beli Potok village, a section up to $2 \mathrm{~m}$ high and more than $5 \mathrm{~m}$ long, formed of conglomerates, semiconsolidated sandstones, gravels and

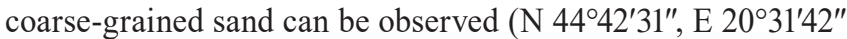
- No.10 in Fig. 1). In the lower part of the section, coarse-grained poorly cemented sandstones and sands are predominant (Fig. 10a, lower part), containing scarce molluscs such as Melanopsis 
rugosa HANDMANN (= M. wolfgangfisheri NEUBAUER, HARZHAUSER, KROH, GEORGOPOULOU \& MANDIC, 2014). Sporadically within the sand, pisoliths with the nucleus of fossil fragments can be observed. Above these, poorly cemented conglomerates and gravels occur with a large number of molluscs (Fig. 10a, b). Pebbles are well rounded and poorly sorted, but there is an internal layering and the appearance of cross stratification. Recrystallized shells of molluscs, mostly congerians is of the main characteristic of the section ((Fig.10c-e). Among the molluscs, the following species were recognized: Mytilopsis ungulacaprae (MÜNSTER), $M$. trnskii (BRUSINA), $M$. balatonica (PARTSCH), Limnocardium banaticum FUCHS, Didacna chyzeri BRUSINA, Melanopsis defensa FUCHS, $M$. rugosa HANDMANN (= M. wolfgangfisheri NEUBAUER, HARZHAUSER, KROH, GEORGOPOULOU \& MANDIC, 2014). Biostratigraphically, the section belongs to the "Lower Pontian", sensu STEVANOVIĆ i.e. it corresponds to the Upper Pannonian Congeria praerhomboidea Zone i.e. a time interval between 8-9 Ma (MAGYAR \& GEARY, 2012). Nevertheless, the aforementioned outcrop belongs to the littoral facies of Lake Pannon.

"Upper Pontian" outcrops up to $10 \mathrm{~m}$ thick have been discovered along the ring road near Mt. Avala. Generally, they con-

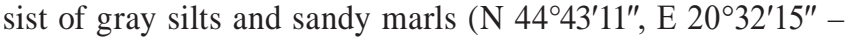
No.11 in Fig. 1). However, they exhibit a yellow-brown colour on the surface (Fig. 11a, b). The lower, older part of the section with a height of $4 \mathrm{~m}$, is composed of brownish to gray, sandy marl (Fig. 11c, d) which contains rare molluscs such as Lymnocardium cf. mayeri (M. HÖRNES), L. riegeli (M. HÖRNES), Mytilopsis croatica (BRUSINA), M. zagrabiensis (BRUSINA). Above these mentioned marls, $\sim 1.5 \mathrm{~m}$ thick gray silts contain a similar fossil association (large candonids prevailing among the ostracods - Fig. 11e). They are intercalated with gray sandy silts (up to $1 \mathrm{~m}$ thick) and a thin interlayer of silts $(10-20 \mathrm{~cm})$ with Lymnocardium zagrabiense (BRUSINA). Besides molluscs, a very abundant ostracod assemblage was also observed: Cyprideis triangulata KRSTIĆ, Hemicytheria josephinae (ZALANYI), H. dubokensis KRSTIĆ, Bakunella dorsoarcuata (ZALANYI),
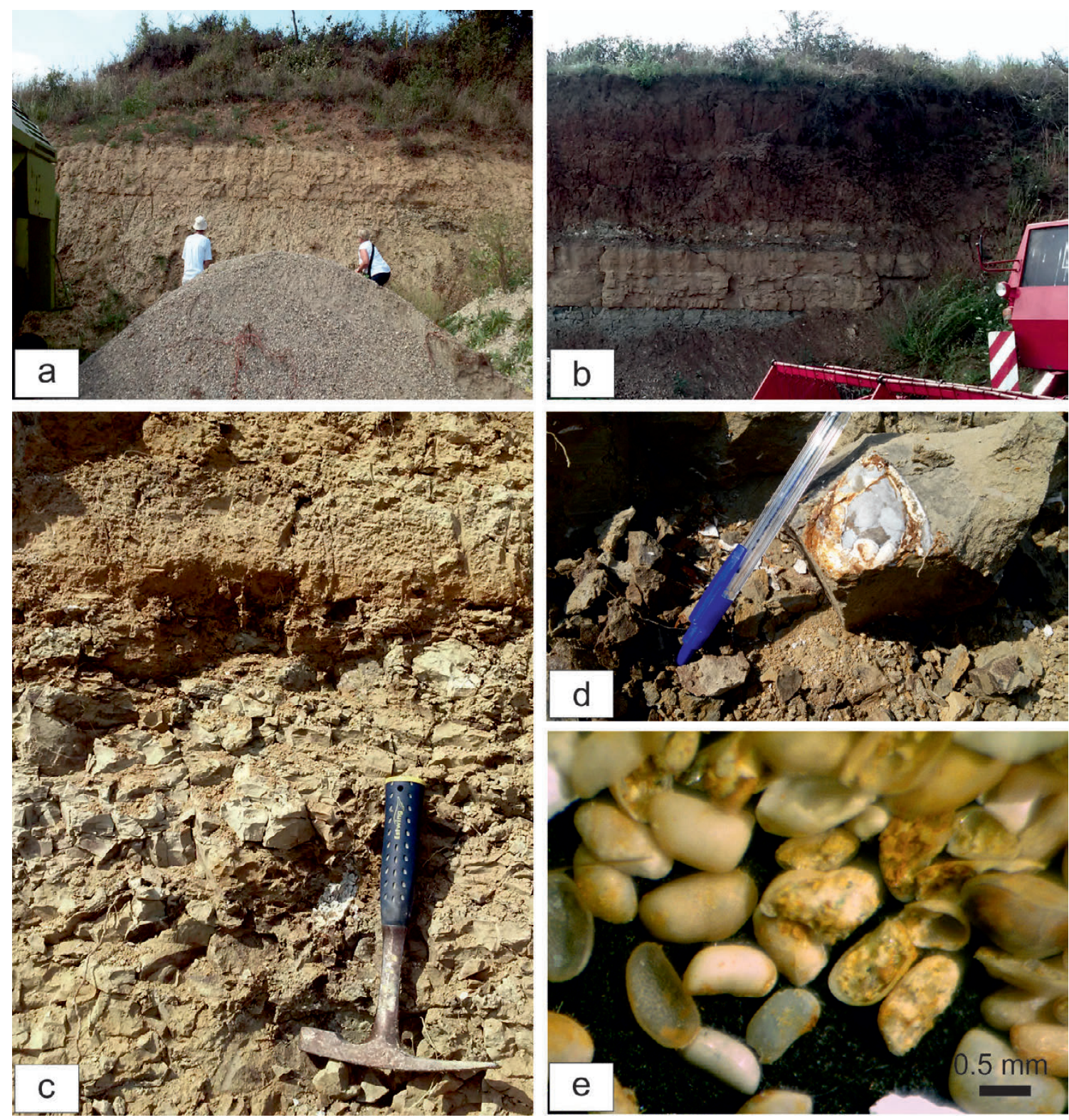

Figure 11. The Upper Pontian (sensu STEVANOVIĆ) light-brown, fine-grained laminated sandy marls (a, b) and gray silts with large molluscan remains ( $c$, d). Detail of the ostracod assemblage (e). 


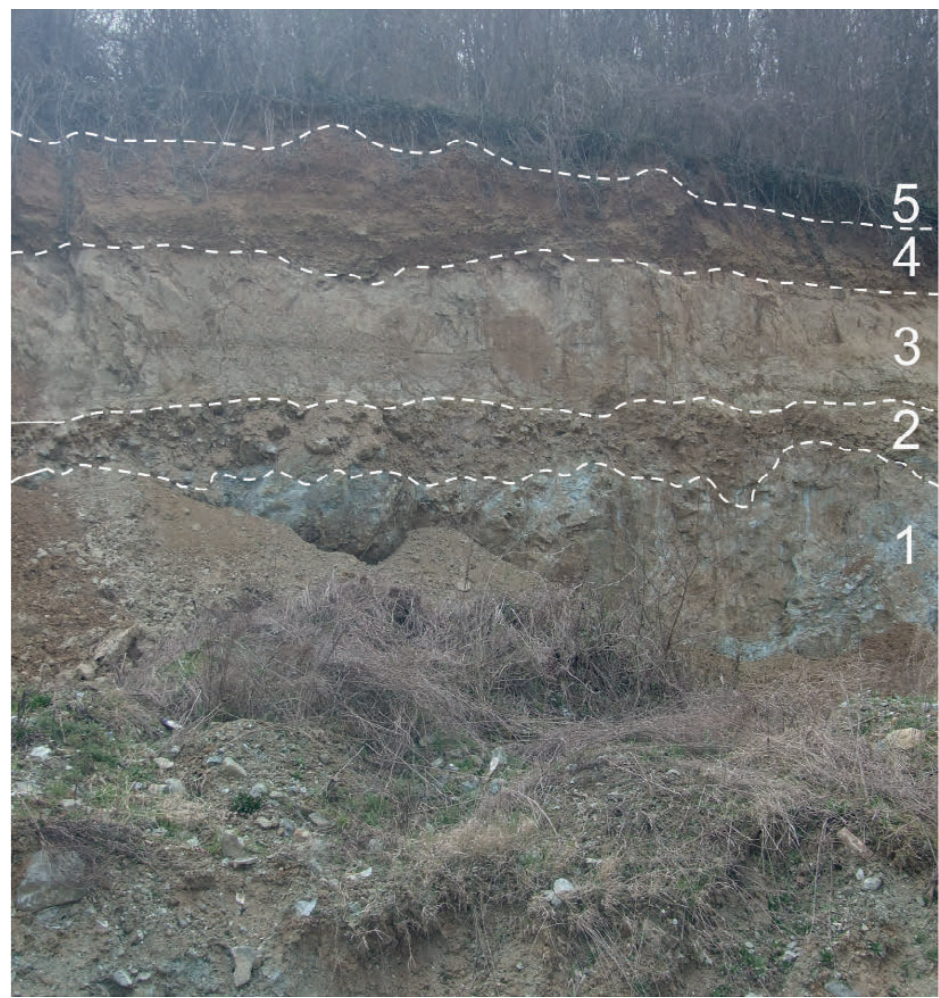

Figure 12. The contact between the blueish-gray serpentinites in the basal part of the section (1) and the Pleistocene delluvial-prolluvial clastites (2) and slope loess sediments (3), and the Holocene delluvial-prolluvial clastites (4) and recent soil at the top of the section (5).

Camptocypria zalanyi KRSTIĆ, Camptocypria flectimarginata SOKAČ, Amplocypris bacevicae KRSTIĆ, Cypria tocorjescui HANGANU, Loxoconcha cumsacui KRSTIĆ, L. schweyeri SUZIN, Thaminocypris sp., Camptocypria sp., Serbiella sp., Pontoniella sp., Lineocypris sp., etc. (Fig. 11e). All determined fossils (ostracods especially) indicate an early "Upper Pontian" (sensu STEVANOVIĆ) age. It is the last level in the section where the fossil remains were found. Above this, there is a light yellow layer of sandy silt (up to $2 \mathrm{~m}$ thick), which contains carbonate concretions of different sizes. Finally, the Quaternary yellowish to brown proluvial-deluvial deposits up to $1 \mathrm{~m}$ thick covers the section.

\subsubsection{Quaternary deposits}

In the studied area, the Quaternary sediments have a relatively small thickness, up to $15 \mathrm{~m}$. They are widespread over the older stratigraphic units. Mostly, they cover the various Miocene as

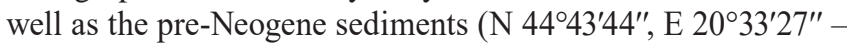
No.12 in Fig. 1; Fig. 12).

They include the Pleistocene proluvial/deluvial coarse to medium-grained clastics, slope loess sequences and, sporadically, old landslides and colluvial products (Leštane, Torlak, Resnik, and Vrčin) up to $12 \mathrm{~m}$ thick.

Holocene deposits are represented by thin alluvial sediments cropping out along the Zavojnička Reka valley and prolluvialdelluvial and colluvial sediments.

Above the right bank of the upper part of the Rakovica Stream, near the road for Mt. Avala and close to the previously described new section of the Sarmatian sediments (see Fig. 8), steeply inclined clastics were discovered (N 444ㄴ $44^{\prime \prime}$, E $20^{\circ} 29^{\prime} 28^{\prime \prime}-$ No.13 in Fig. 1). They consist of breccias as well as conglomerates with clasts of Cretaceous sediments, quartzites, dacito-andesites. Rock boulders and cobbles are sub-rounded and poorly sorted a maximum diameter of $<40 \mathrm{~cm}$ (Fig. 13a, b). Abundant reworked Badenian and Sarmatian fragments are included in these deposits (Fig. 13c). Since these clasts are found in the vicinity of the Rakovica fault, it can be assumed that their genesis is related to the tectonic movements of structural blocks around the Rakovica fault, which resulted in a denivelation of terrain, formation of steep slopes and predominant gravitational processes (e.g. proluvial processes) with deposition of clastic bodies. These clastics were probably generated during the early Pannonian.

\subsection{The subsurface data}

As an exception to the collected surface data from the aforementioned outcrops and sections, an additional two shallow boreholes (BT1-2 and BT1-3) have been analyzed (see Fig. 1). They were drilled at the top of the hill near Leštane, close to the E75 highway, for the purpose of a future railway tunnel "Bubanj Potok".

\subsubsection{Borehole BT1-2 (N 44²3'10", E $20^{\circ} 34^{\prime} 01^{\prime \prime}$ )}

A few different stratigraphic units were recognized within the $90 \mathrm{~m}$ of core $\log$ (Fig. 14). At the base of the well (depth interval 38-90 m), more than $50 \mathrm{~m}$ of dark to greenish serpentinized peridotites and serpentinites were discovered. In the upper part, the serpentinites are tectonized and contain a lot of reticulate fractures. These fractures are infilled with magnesite. The serpentinites are overlain by a package of hard serpentinized breccias (at the depth interval 27-38 m) more than $10 \mathrm{~m}$ thick, which contain serpentinite fragments of different size, representing the transition zone towards the overlying Miocene and Quaternary cover. Transgressively on the serpentinized breccias, variegated coarse-grained sands and conglomerates of the Bučvar member (The Slanci Fm.) are up to $7 \mathrm{~m}$ thick and represent the continental-lacustrine cycle of the early Miocene (DOLIĆ, 1997, 

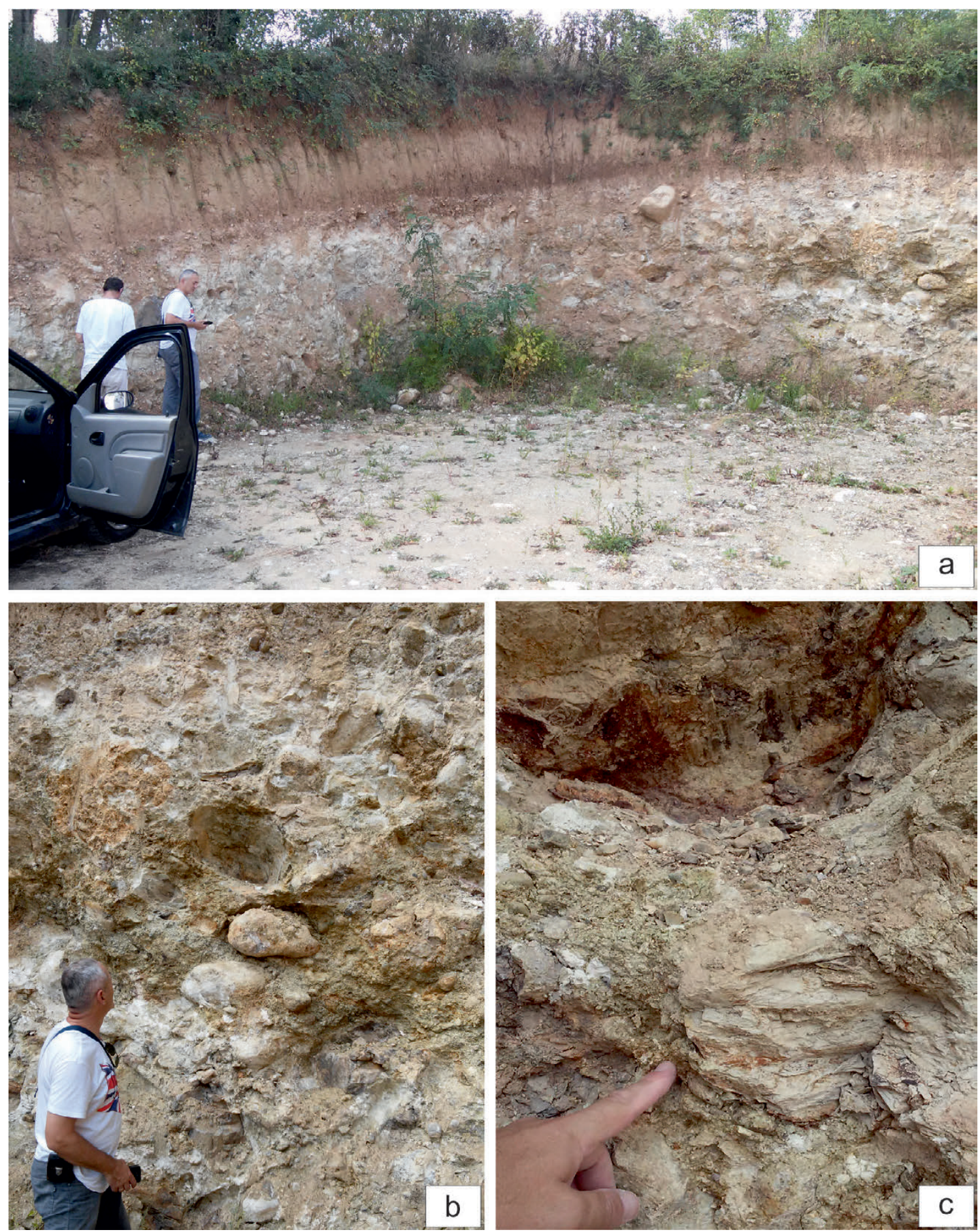

Figure 13. Coarse-grained breccias and conglomerates with clasts of Cretaceous sediments, quartzites, dacito-andesites (a, b) and redeposited material from the Badenian and Sarmatian deposits (c).

1998). There are no fossils identified within this unit which represents the lateral continuation of the previously mentioned similar sediments from the Bučvar and Rakovica streams (see Fig. 3). At the same time, at $20.2 \mathrm{~m}$ below the surface, the Middle Miocene Badenian basal clastites (5.2 m thick) indicate the marine transgression which occurred in this area. They consist of different clasts of gravel, sandstones and carbonate rocks. Sporadically, only fragments of mollusc shells could be visible. Typical the Leitha limestone with lot of molluses (Chlamys sp., Glycymeris sp.) and corallinacean alga (Lithotamnion sp.) was found at the depth interval of $6.5-15.0 \mathrm{~m}$. At the top of the lime- stone, a thin crust of limestone decomposition is visible. Finally, at the at the top of core, up to $6.5 \mathrm{~m}$ of poorly cemented loess-like sediments constitute the last stratigraphic unit.

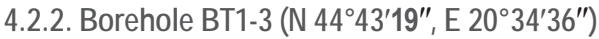

The second borehole, drilled in the vicinity of BT1-2 (Fig. 1), reached the ?Lower Miocene reddish series at a depth of $47 \mathrm{~m}$ (the Bučvar Member of Slanci Fm.; DOLIĆ, 1997, 1998 - see Fig. 15). Stratigraphically, these two wells can be easily compared in their uppermost 30 metres. Herein, only three units were recognized and, practically it represents the upper portions of well 


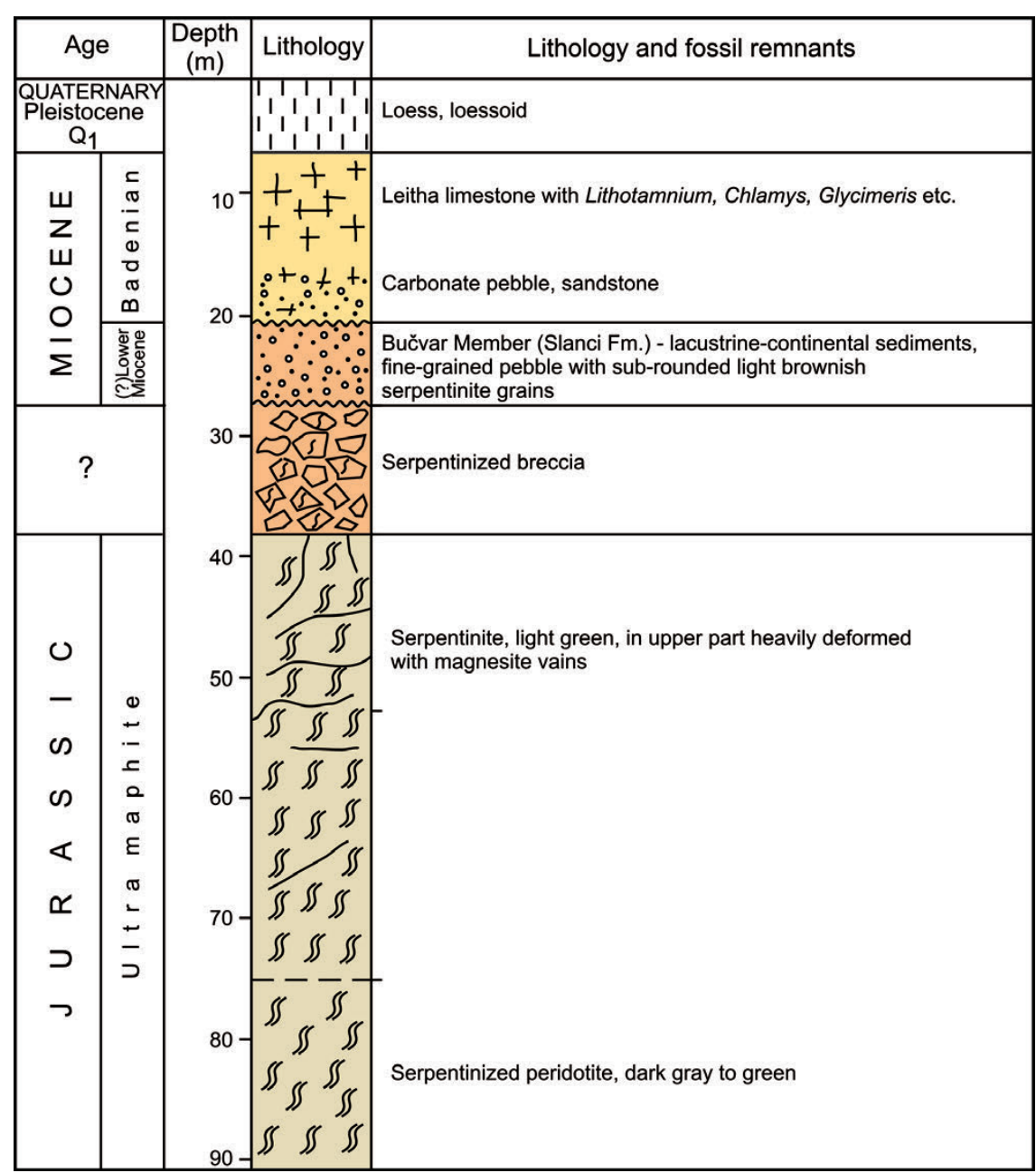

Figure 14. Lithostratigraphic log of borehole BT1-2, in the vicinity of Leštane.

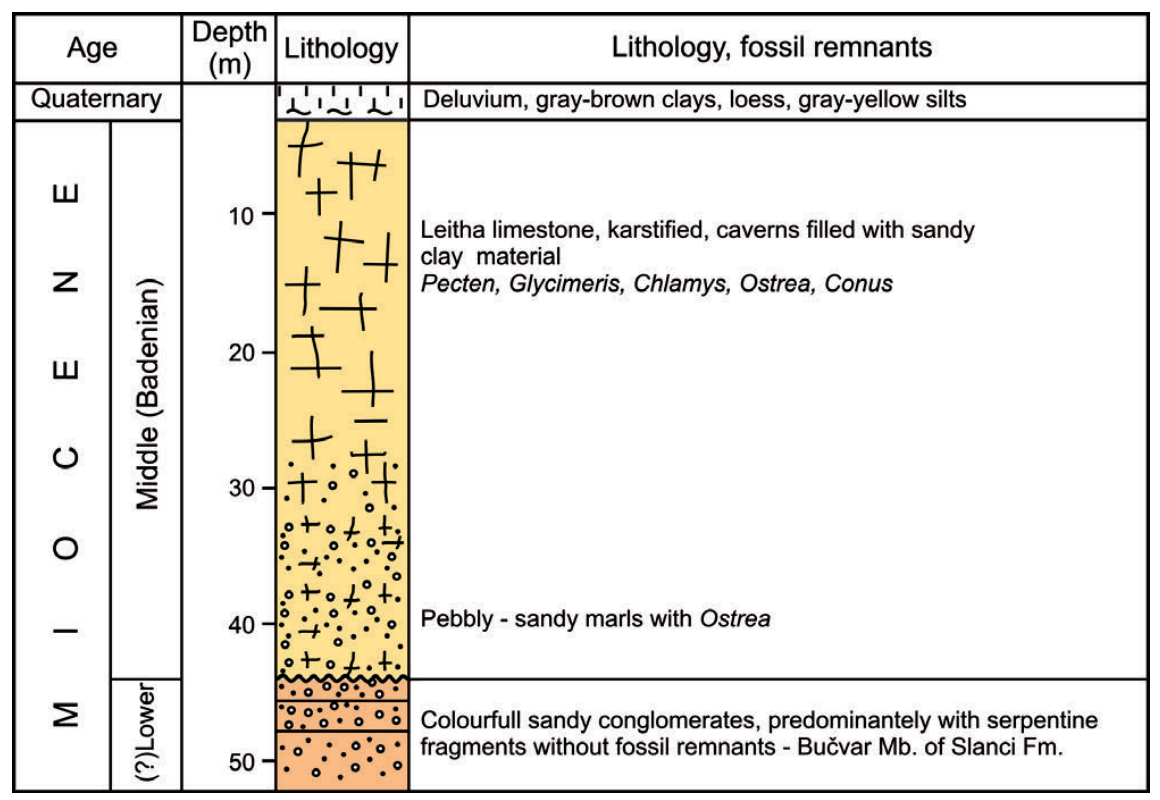

Figure 15. Lithostratigraphic log of borehole BT1-3, in the vicinity of Leštane.

BT1-2. However, the middle part of the core $\log$ (depth interval 4-43 m) is represented by the marine Badenian unit (basal clastites, gravel and sandstones and the Leitha sandy limestone). Many fossil remains confirm the Badenian age (Chlamys sp., Os- trea sp., Conus sp., red algae, bryozoans, corallinacean algae (Lithotamnion sp.), etc. At the top of the drilled succession, the uppermost portion (c. 4 m), of thick deluvial yellowish silts, gray silty clays and loess sediments comprise the limestone cover. 


\subsection{Geomorphology and some structural properties of the study area and its vicinity}

The lack of quality information i.e. a small number of measured structural elements (no systematic measurements of the direction of inclination of layers, stress analysis, etc.) as well as the morphological diversity of the area were the main reasons for geomorphologic consideration in order to try to identify the position of neotectonic active structures. We tried to support and possibly connect the afore-mentioned stratigraphic results with geomorphologic observations of the relief. In addition, these observations are connected with an estimation of the structural elements based on a DEM terrain model and general (not systematic) analysis of linear relief structures. In other words, this approach was forced due to circumstances but, in our mind, useful.

The wider study area occupies approximately $140 \mathrm{~km}^{2}$. Morphologically, it can be divided into two parts: a composite hilly landscape consisting of the Torlak Hill (310 m) and Mt. Avala $(511 \mathrm{~m})$ and surrounding low hilly area $(200-250 \mathrm{~m})$ that are both dissected by the NNW-SSE striking Topčiderska Reka and Zavojnička Reka valleys (Fig. 16). These valleys represent the principal drainage systems of the study area. At the same time, Torlak Hill and Mt. Avala represent a drainage divide because the Topčiderska Reka water course flows to the Sava River whereas the Zavojnička Reka runs to the Danube River. At many locations, secondary E-NE directed streams have

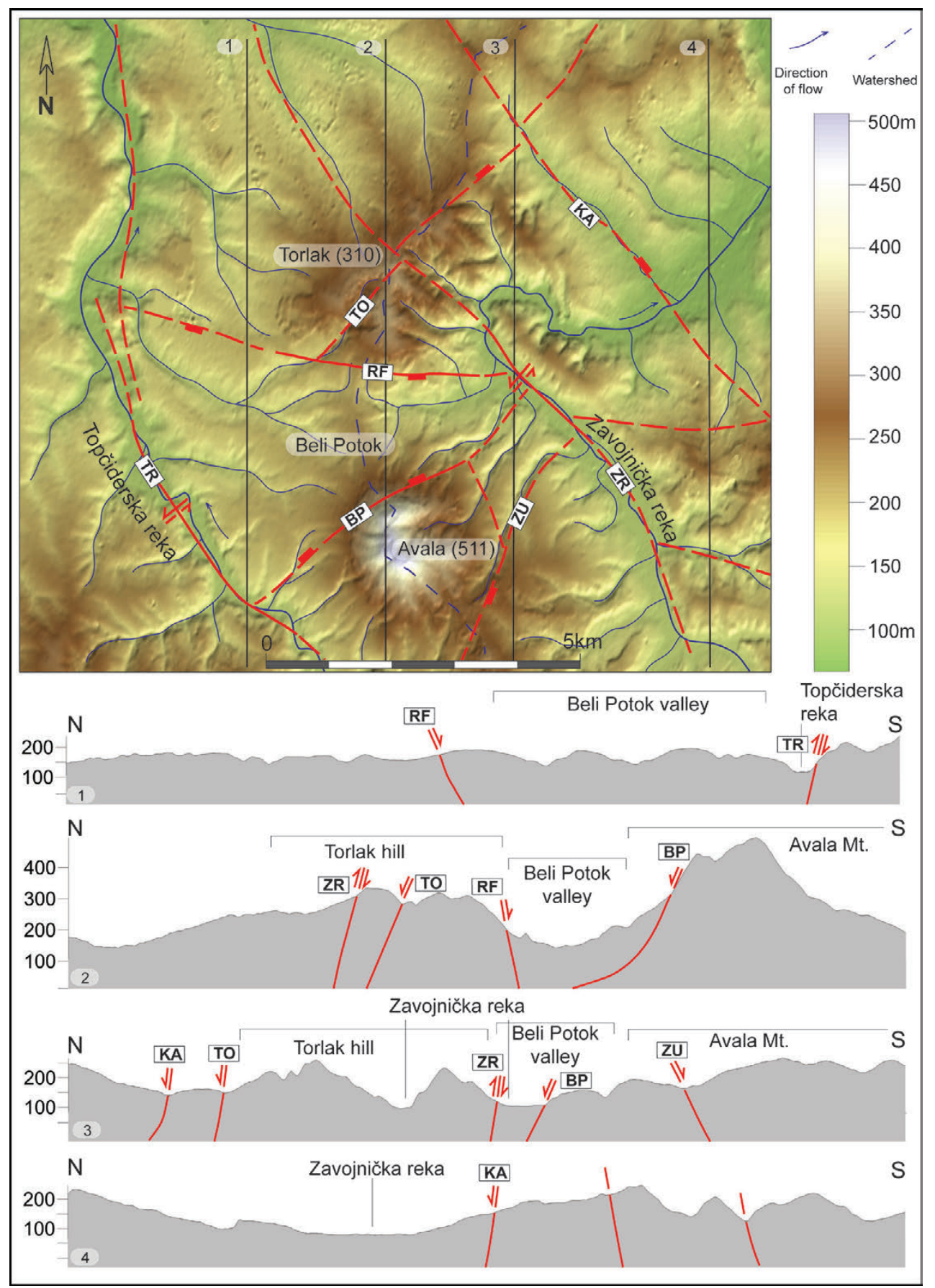

Figure 16. The digital elevation model (DEM) of the studied area with the positions of the two main drainage systems (Topčiderska reka and Zavojnička reka) as well as the topographic cross-sections with locations of the main faults (1-4). For the legend, see Fig. 1. The original elevation data provided by Japan Aerospace Exploration Agency (JAXA). 


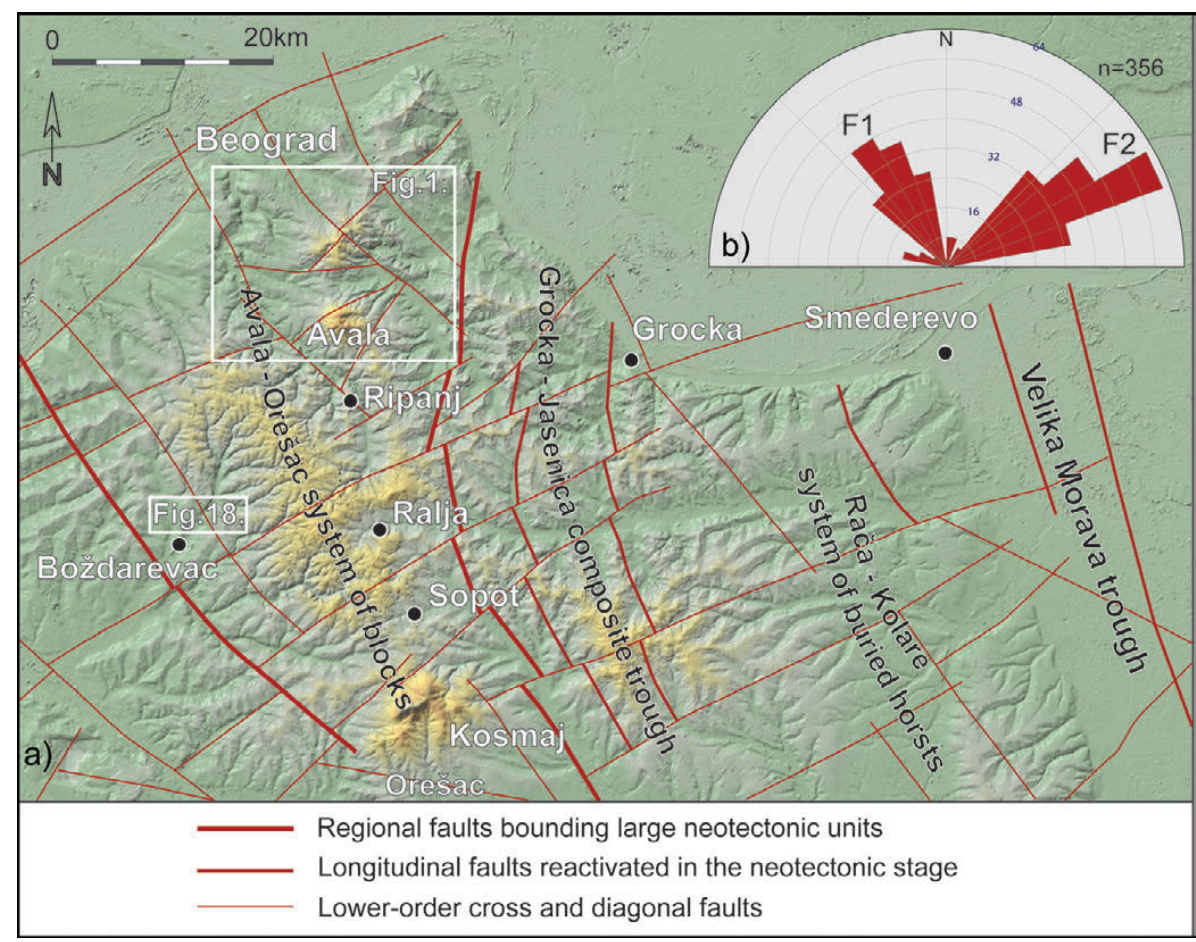

Figure 17. a) Map of the orientation of linear structures in the broader study area. Main faults and neotectonic units separated according to MAROVIĆ \& KNEŽEVIĆ (1985), TOLJIĆ (1996) and MAROVIĆ et al. (2007); b) Rose diagram plotted from the map of linear structures. Measurements of the orientation of fault traces were based on linear lengths of approximately $2 \mathrm{~km}$.

asymmetric valleys with gently dipping northern sides and steeper southern slopes (Fig. 16, Profiles 1-4). In some places, the lower parts of the streams are covered by recently formed colluvial sediments from currently active slope gravitational movements, i.e., landslides and/or slope creeping processes (Fig. 12, northeastern slope of Torlak Hill). These sliding processes suggest instability of the steep geologically conditioned slopes in the study area affected by either geological heterogeneity or exhumation along the recent inactive faults (MAROVIĆ et al., 2007; KOVACS et al., 2015 and references therein).

Based on these relief data as well as the observed Topčiderska Reka and Zavojnička Reka river flows that are obviously structurally controlled (see Figs. 1, 17 and 21), it is reasonable to argue that drainage system and landscape evolution during Pontian-Quaternary are conditioned by uplift of the Torlak block which has already been elevated since the early Upper Miocene (Fig. 1). Uplift of the Torlak block was probably controlled by the NE- SW striking Torlak fault as well as the E-W directed Rakovica fault and its segments (Figs.17 and 21). This structure defines the northern edge of the Beli Potok trough which represents the area of subsidence filled by the Upper Miocene sediments (Figs. 17 and 20).

Except for some individual measurement of faults and strata orientation within the different Miocene units, the analysis of the fault systems was performed by the interpretation of digitally generated terrain of the wider area of Mt. Avala (Fig. 17a) which is supported by the known facts (e.g. MAROVIĆ \& KNEŽEVIĆ, 1985; TOLJIĆ, 1996; MAROVIĆ et al., 2007). The main assumption was the tectonic control of the orientation of river valleys and linear features that were recognized at the given map scale. In addition to the authors rare measurements, the fault kinematics and timing in the wider area were taken from the aforementioned references. Recognized structures were measured as line segments of given length $(\sim 2 \mathrm{~km})$ and plotted on a rose diagram
(Fig. 17b). The statistical interpretation of the linear features (orientation of river valleys, changes of slope angles, and sharp turns of water flows, etc.) as well as the main fault categories separated in the wider area of Mt. Avala (MAROVIĆ \& KNEŽEVIĆ, 1985; MAROVIĆ et al., 2007) indicates the two main trends of the fault network. First, the (F1) fault system is generally oriented in a NW - SE direction (Fig. 17a, b). In the study area, the Topčiderska Reka (TR), Zavojnička Reka (ZF) and Kaludjerica (KF) faults belong to this system. Later, from the post-Sarmatian time, some of them were reactivated in the compressional regime and show a reverse character (Figs. 1, 16, 18 and 21). This system is mainly inherited from the collisional processes that happened during Late Cretaceous and Paleogene times (MAROVIĆ et al., 2007). This collision is classically interpreted as post Jurassic obduction, large scale faulting and thrusting within the innermost units of the Dinarides and with a general NW - SE strike (along the central part of the Balkan Peninsula) (TOLJIĆ et al., 2018). Structures related to these events are best documented in the pre-Neogene formations in the study area (TOLJIĆ, 2016). During the later tectonic events these faults were reactivated (MAROVIĆ et al., 2007; see Fig. 18). The younger, second fault system (F2) is related to the formation and later evolution of the Pannonian basin. The (F2) faults system orientation reflects a general ENEWSW direction with a pronounced NE-SW direction (Fig.17a, b). These events were controlled by extensional regimes and subsequent tectonic inversion (MAROVIĆ et al., 2007). In the study area, the Rakovica (RF), Beli Potok (BP) and Torlak (TO) faults are recognized within this system. They are responsible for the dissection of the older faults from the F1 system (Fig. 17a) and along these ENE - WSW oriented faults the block structures with pronounced vertical movements were developed (Figs. 20 and 21). Besides this orientation, faults which were reactivated in the late Miocene or neotectonic stage (see Fig. 18), exhibit a direction 


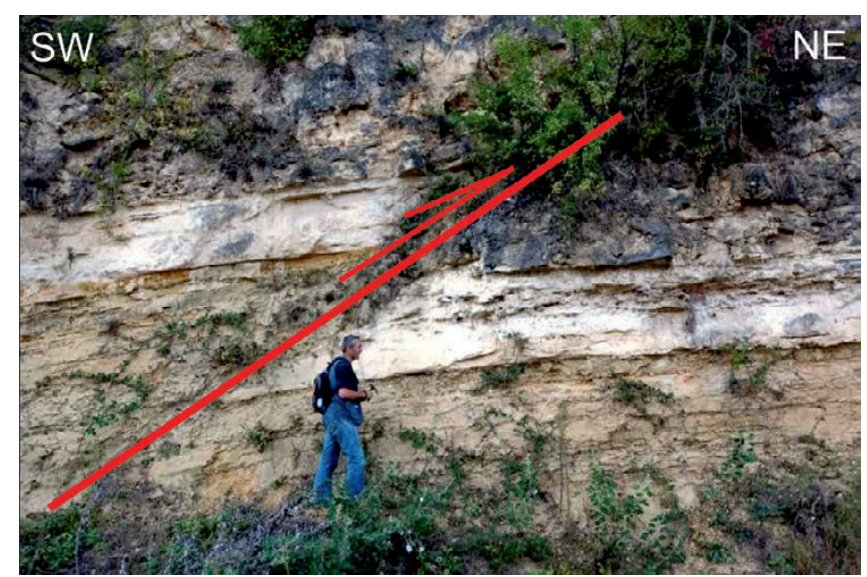

Figure 18. The reverse fault within the Sarmatian sediments as a consequence of Late Miocene-Pliocene compressional tectonics (village Boždarevac, southwest of Mt. Avala).

similar to the F1 structure and they outline block structures in the studied area (Figs. 1, 17, 21).

In the study area, there is no measured fault that follows the late Miocene post-rifting subsidence and Pliocene compressional tectonics. However, a nice example is found in Boždarevac (N $44^{\circ} 32^{\prime} 27^{\prime \prime}$, E $20^{\circ} 22^{\prime} 41^{\prime \prime}$ - Fig. 17a), 20 km southwest of Mt. Avala where there is pinpointed movement along a fault which resulted in vertical displacement (up to 2.5 metres) of the Sarmatian fossiliferous sands and limestones (Fig. 18). This structure with a measured dip direction and dip angle of the fault (214/48) is part of the reverse faults which were reactivated in the NE-SW oriented compressional stress-field. Faults of this direction are statistically recognized as linear structures that belong the first fault system (F1). Furthermore, this structure corresponds to the similar NW-SE orientation of the large fault structures observed in the study area such as the Topčiderska reka and Zavojnička reka faults (Figs. 20 and 21). Also, this system of structures is kine- matically and spatially correlative with those previously recognized within the Pannonian basin and its southern margins (e.g. BADA et al. 2007; MATENCO \& RADIVOJEVIĆ, 2012; TOLJIĆ, 2016; TOLJIĆ et al., 2018).

\section{DISCUSSION AND INTERPRETATION}

The Mio-Pliocene tectonic framework of the study area is controlled by the processes at the southern margin of the Pannonian basin (MATENCO \& RADIVOJEVIĆ, 2012; BALÁZS et al., 2016; SANT et al., 2018). As these processes are well documented in the central part of the basin based on subsurface data (HORVÁTH et al., 2015, MATENCO et al., 2016, BALÁZS et al., 2017, etc.) they could be inferred for the area of Mt. Avala.

New research findings collected in this study have shown that the oldest continental-lacustrine sediments (e.g. Bučvar clastites) are present over larger areas than previously known (clastites are found in the vicinity of Leštane and Resnik, see Fig. 19). In this study, however, there is insufficient information about the sedimentary conditions in which they were formed, especially since these deposits are most often destroyed by subsequent erosion processes (DOLIĆ, 1997). During the wellknown Badenian marine transgression, a Paratethys bay was established in the wider area north of today's Mt. Avala which includes Torlak, Leštane and its vicinity (Fig. 17). Mt. Avala represents a unique horst including the block of present day Kosmaj Mountain (MAROVIĆ \& KNEŽEVIĆ, 1985). Its significant differentiation begins in the early Sarmatian when, following the faults of NE-SW and E-W directions, the subsidence and formation of smaller bays and troughs flooded by the waters of Paratethys were carried out. Such characteristics are reflected in the local structural units in the eastern section of the studied area, i.e., the Ripanj, Ralja and Sopot bays; see Fig. 17 (MAROVIĆ \& KNEŽEVIĆ, 1985). In that sense, our findings of new Sarmatian sections and outcrops in the area of the Rakovica stream valley are important to support analogous scenarios in the northwestern part of the study area. The Beli Potok trough is similar, which subsided later in the late Pannonian and

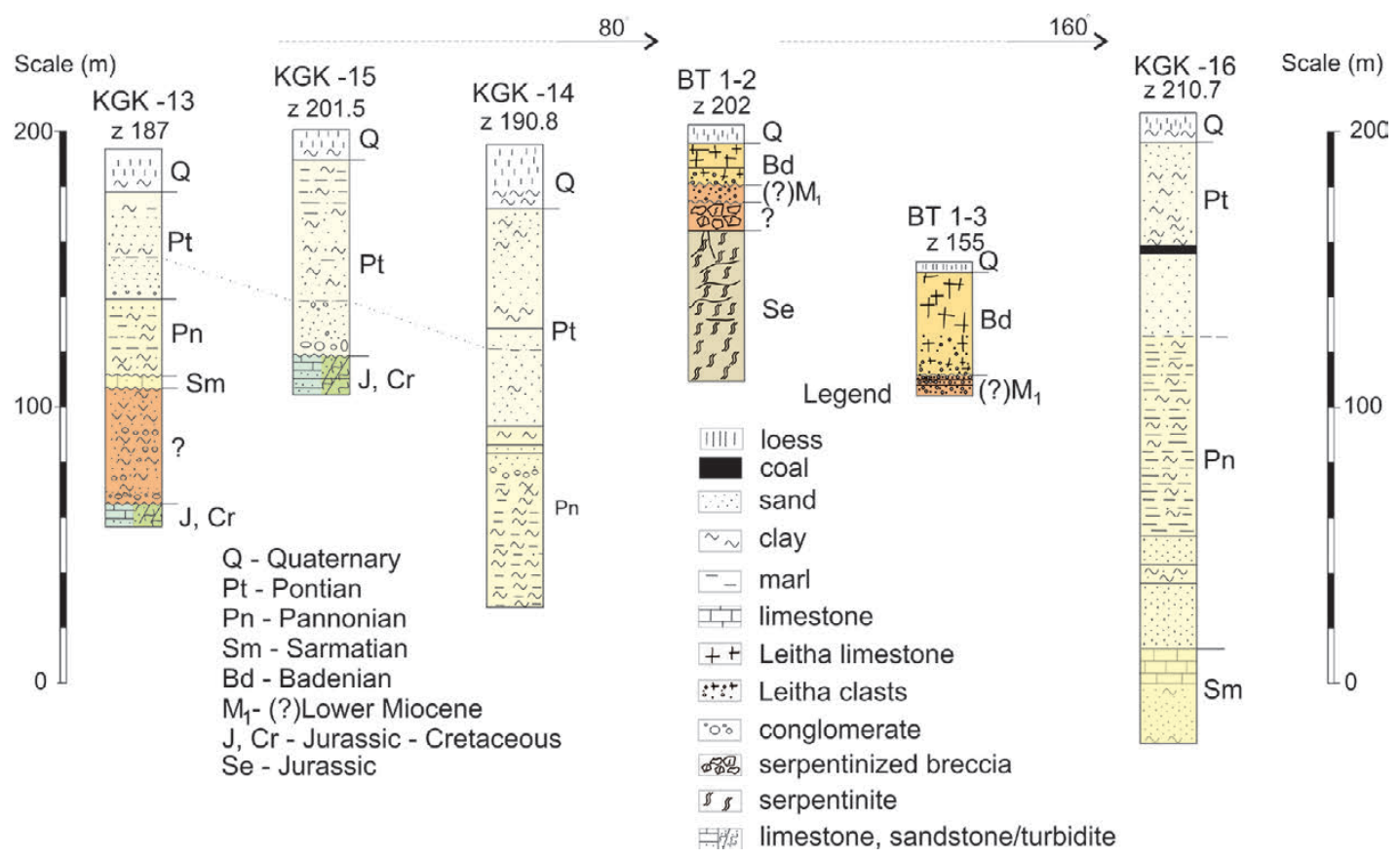

Figure 19. Comparative lithostratigraphic columns of the boreholes around Mt. Avala. The data concerning the KGK boreholes are taken from KNEŽEVIĆ (1989, 1990). For the location of boreholes, see Fig. 1. 
Pontian (sensu STEVANOVIĆ) (Figs. 17, 20). It was a consequence of the uplifted blocks located in the southwestern parts of the Velika Morava trough (MAROVIĆ \& KNEŽEVIĆ, 1985; DJOKOVIĆ \& MAROVIĆ, 1990; MAROVIĆ et al., 2007 - see Fig. 17). Later, during the Pontian, the Beli Potok trough was reduced and directed to the east, towards the Grocka-Smederevo area (MAROVIĆ \& KNEŽEVIĆ, 1985; see Fig. 17). From a geodynamic point of view, The Beli Potok trough is an interesting structure because within the Avala structural unit there are differential movements of the faults separating the local blocks. In the previous studies (e.g. LASKAREV, 1931) the existence of a large linear structure, the so-called the Rakovica fault was noticed which locally separates the Torlak horst from the trough, which STEVANOVIĆ (1951) distinguishes as the Beli Potok trough (Fig. 20). The Beli Potok trough (224 m a.s.1.) situated between Mt. Avala (511 m a.s.l.) and Torlak Hill (310 m a.s.l.) is a local tectonic structure filled with Upper Miocene sediments. According to STEVANOVIĆ (1951) and EREMIJA (1977b), it is an asymmetric trough in which Neogene deposits are slightly folded in a shallow syncline. Along Mt. Avala itself, the sediments of the lower Pontian discordantly overlie the Mesozoic palaeorelief (Fig. 20). In contrast, in the northern part, at the base of Torlak Hill, there are Pannonian marls underlying the Pontian deposits. The Torlak Hill (horst) is composed of Cretaceous and Middle Miocene Badenian and Sarmatian sediments.

Our research has generally confirmed the view of the aforementioned authors, but new insights have emerged on the nature and characteristics of the Beli Potok trough. Namely, on the left bank of the Rakovica Stream near the Avala road, the transitional section between the slightly dipping Sarmatian laminated marls and fine-grained sand and the Lower Pannonian steeply inclined sandy marls was discovered (Fig. 20). Some $300 \mathrm{~m}$ further to east (210 m.a.s.1.), the younger Pannonian marls with well-known Congeria czjzeki were discovered. These new findings confirm the previous investigations and indicate more than a hundred metres of vertical movement of the blocks in this area (e.g. MAROVIĆ $\&$ KNEŽEVIĆ, 1985). Furthermore, these new findings are corroborated with the previously studied borehole KGK-14 (190.8 $\mathrm{m}$ a.s.1.) downstream from the Rakovica fault line (Fig.19).
The drilling was carried out within the Beli Potok trough in which sediments of the Upper and Lower Pontian (sensu STEVANOVIĆ) were determined down to a depth of $105 \mathrm{~m}$ and the Upper Pannonian in the lower portion of the drilled succession, at a depth of about 155 m (KNEŽEVIĆ, 1989 - see Fig. 19). Besides, it was discovered that similar Pontian sediments were deposited over the palaeorelief of Jurassic and Cretaceous rocks in the area of Pinosava, e.g. borehole KGK-15 (Fig. 19). At borehole KGK-13 near Resnik (187 m a.s.l) these Pontian sediments overlie the Pannonian marl, Sarmatian limestone and the Bučvar clastites of the ?Lower Miocene (Fig. 19). The vertical displacement of the aforementioned sediments along the Rakovica fault is more than $100 \mathrm{~m}$. In addition, this movement was determined based on comparison of the absolute altitude of the layers of the Upper Pannonian marls on the surface and the marls of the same age in borehole KGK-14 (the difference is more than $110 \mathrm{~m}-$ KNEŽEVIĆ, 1989; Fig. 19). The collected data within this work have confirmed that the formation of the Rakovica fault is related to the early Pannonian and that sedimentation in the Beli Potok trough occurred between the late Pannonian to the late "Pontian" (sensu STEVANOVIĆ). Palaeogeographically, during the Late Miocene, in the Beli Potok area there was a Lake Pannon bay which was connected to the northern one in the Grocka-Smederevo area (MAROVIĆ \& KNEŽEVIĆ, 1985; MAROVIĆ et al., 2007).

During the Pliocene and Quaternary, the southern margin of the PB and the Peri-Pannonian realm (the present day Šumadija part of Serbia) experienced a continental phase of development (MAROVIĆ et al., 2007; SUŠIĆ et al., 2015). The contemporary spatial position and absolute altitude of the Miocene deposits in the elevated and subsided blocks can be taken as evidence of the tectonic activity in the wider part of Mt. Avala. On Torlak Hill the Badenian sediments are located at altitudes above $300 \mathrm{~m}$. Rocks of the same age were drilled in the Grocka depression (the local peripheral structure of the Velika Morava trough) at depths between 1000 and $1100 \mathrm{~m}$, i.e. between 900 and $1000 \mathrm{~m}$ absolute altitude (KNEŽEVIĆ et al., 1994). This means that in the study area the significant vertical movements began in post-Badenian time (the post-rift phase) which continued to the Mio-Pliocene boundary (MAROVIĆ \& KNEŽEVIĆ, 1985; MAROVIĆ et al., 2007). Due to differential rock uplift in the vicinity of the Beli

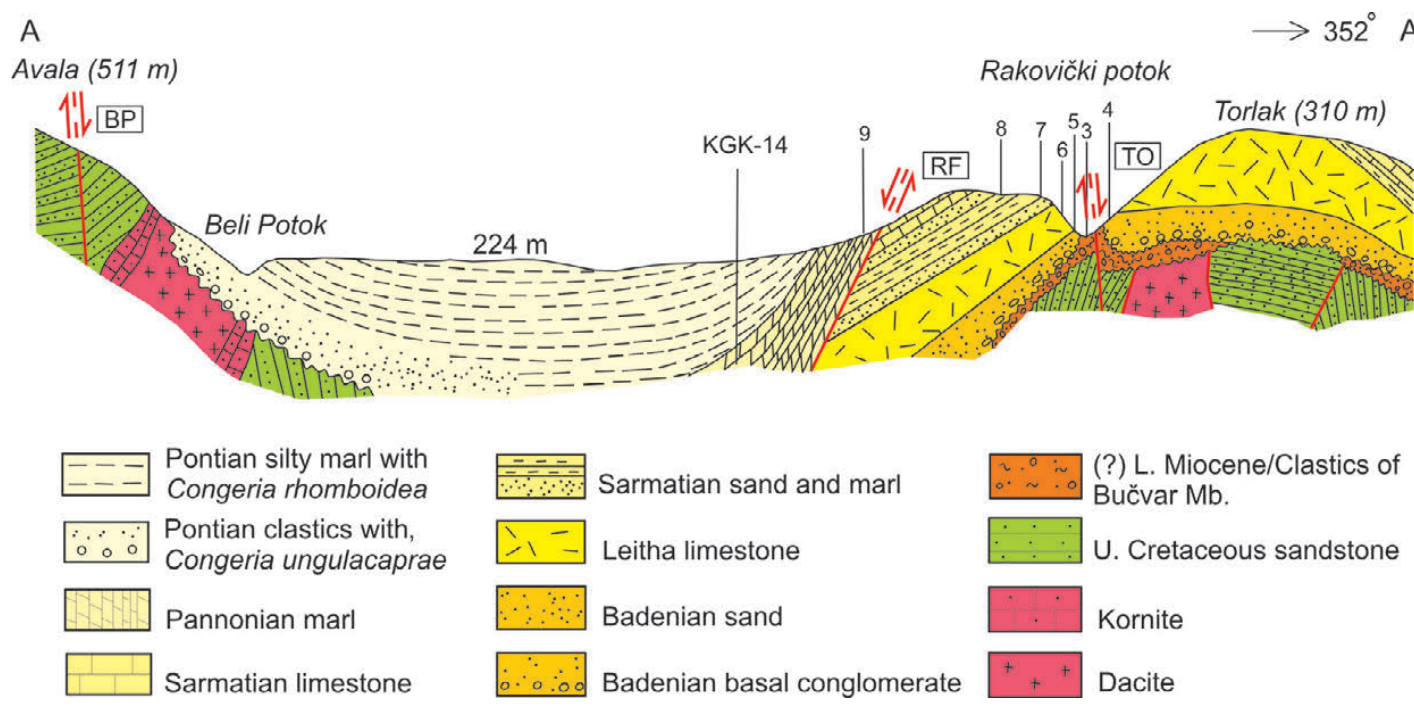

Figure 20. The generalized geological cross-section through the Beli Potok trough (modified and upgraded after STEVANOVIĆ, 1951). Numbers indicate the studied outcrops that are located near the profile line. For the faults key, see Fig. 1. Note: Scale is adapted to better illustrate the geological relationships. 


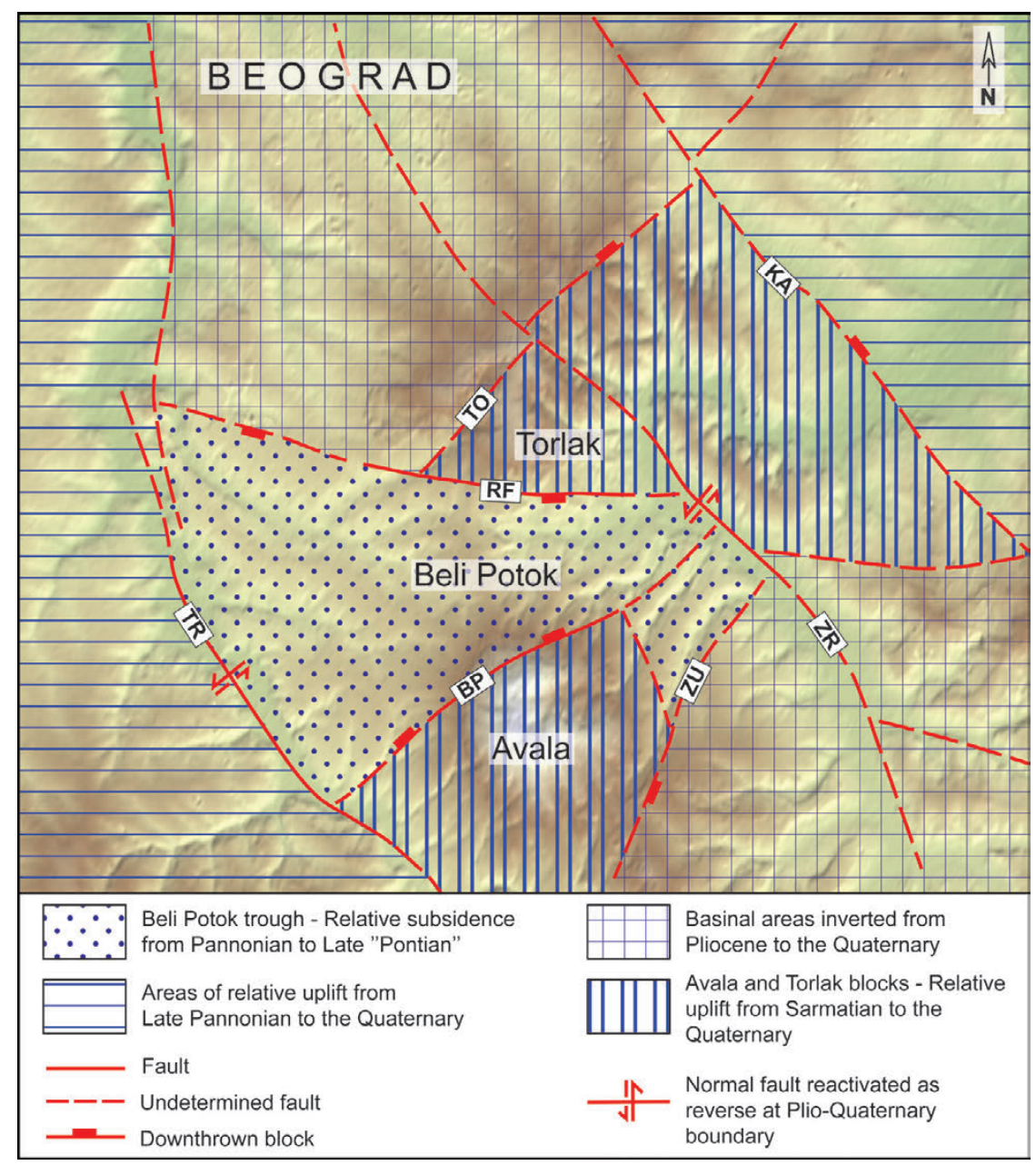

Figure 21. Neotectonic sketch map of Mt. Avala and the surrounding area (modified after DJOKOVIĆ \& MAROVIĆ (1990), TOLJIĆ (1996) and MAROVIĆ et al. (2007). Abbreviations: RF - Rakovica fault, BP - Beli Potok fault, TR - Topčiderska Reka fault, ZR - Zavojnička Reka fault, TO - Torlak fault, KA - Kaludjerica fault and ZU Zuce fault. Note: Traces of the faults are taken from the mentioned references. Topography was generated from data provided by the Japanese Aerospace Exploration Agency (JAXA).

Potok trough, late Miocene sediments located at higher altitudes were destroyed by erosion. The younger and softer sediments, less resistant to abrasion, were eroded (see Fig. 12). As a consequence, the youngest Neogene deposits created during the late Pannonian (the latest Miocene, Pontian sensu STEVANOVIĆ) were preserved only at the peaks of the lower hills (KNEŽEVIĆ, 1990; borehole KGK-16, Fig. 19). Ongoing rock uplift is documented at the peaks around the Zavojnička Reka valley and Leštane, where the Mesozoic ultramafites were discovered (e.g. Leštane and its vicinity - unpublished data). This is confirmed within this study, in the analyzed boreholes BT1-2 and BT1-3 where the Bučvar clastites and the Leitha limestone cover the serpentinites. Based on these observations, it can be assumed that a significant part of the studied area was covered by different Miocene and Pliocene sediments.

The neotectonic map of the study area constructed in this work comprises several blocks with different kinematics from the Miocene to the present (Fig. 21). The most prominent topographic feature of the studied area is the Avala. The Avala block is defined by the Topčiderska Reka (TR), Beli Potok (BP) and Zuce faults (ZU). The presence of the late Miocene sediments on the mountain slopes suggests that this structural unit was uplifted during Sarmatian times. This is based on the fact that the youngest sediments on the slopes of Mt. Avala are "Pontian" clastics which directly overlie the Mesozoic rocks (Fig. 20). During the early middle Miocene, together with the Torlak block, it represents a horst structure that extended southwards to Mt. Kosmaj (MAROVIĆ et al., 2007). The Torlak block, which is situated north of Mt. Avala, is covered with pre-Badenian and Badenian sediments at about $300 \mathrm{~m}$ a.s.l. It indicates the upward relative movements of the block that started at the end of the Sarmatian and continues to recent times (e.g. in a few boreholes near Leštane) (MAROVIĆ \& KNEŽEVIĆ, 1985; RUNDIĆ et al., $2015,2017)$. The presence of the pre-Badenian clastics in a few boreholes in the area of Resnik at depths below $100 \mathrm{~m}$ (the westernmost part of the Beli Potok trough) where they overlie the Mesozoic rocks support this fact (e.g. KNEŽEVIĆ, 1989). The block is formed by movements along the Rakovica fault system (RF) and the Torlak fault (Fig. 20).

In respect of the geomorphologic properties of the unusual flow/geometry of the Zavojnička Reka near the Torlak block, we don't have documented data. But, based on some observations by MAROVIĆ \& KNEŽEVIĆ (1985) and DJOKOVIĆ \& MAROVIĆ (1990), it could be potentially associated with rather fast uplift of the Torlak block from the Pliocene to recent time. According to DJOKOVIĆ \& MAROVIĆ (1990) and TOLJIĆ $(2006,2016)$ and the documented structural measurements of different Mesozoic units in the study area, the Zavojnička Reka is controlled by the local fault system with its N-NW to S-SE direction. After the "Pontian" cycle of sedimentation (Late Pannonian, Latest Mio- 
cene) between the Avala and Torlak structural blocks, the fluvial phase of relief formation began (MAROVIĆ \& KNEŽEVIĆ, 1985). During that time, as the uplift of Torlak Hill progressed, the Zavojnička Reka changes its flow from SE-NW and turns towards the E-NE, away from Torlak. This activity led to the formation of the new, local structure along which the new flow was established (Fig. 21).

The Beli Potok trough is situated between these two relatively uplifted blocks. It is formed by the Rakovica and Beli Potok faults. Morphologically it comprises several valleys of creeks flowing towards Zavojnička and the Topčiderska Reka. Superposition of the Neogene formations within the trough and the neighbouring blocks indicates that the subsidence started late in Pannonian time. This trough is kinematically and spatially correlative with similar structures observed south of Fruška Gora Mt. (e.g. Sava half-graben) (MATENCO \& RADIVOJEVIĆ, 2012). Unfortunately, there is no seismic section within the studied area that can further support these interpretations.

From the structural point of view and according to the tectonic settings of Šumadija and part of NW Serbia, the area of the Torlak hills and Mt. Avala belongs to the Avala-Orešac structural unit characterized by blocky structure (MAROVIĆ \& KNEŽEVIĆ, 1985; MAROVIĆ et al., 2007). According to MAROVIĆ \& KNEŽEVIĆ (1985), TOLJIĆ $(1996,2016)$ and MAROVIĆ et al. (2007), the Avala-Orešac structural unit was dissected into smaller blocks by systems of NE-SW (partially E-W) striking Mio-Pliocene faults (or remobiled the older ones). The Avala horst as the largest structure in the aforementioned zone extends from the Sava and the Danube rivers in the north to the Sopot and Stojnik in the south (MAROVIĆ \& KNEŽEVIĆ, 1985; MAROVIĆ et al., 2007). The Avala horst is oriented almost meridionally, and it is constrained on all sides by extensional faults related to the syn-rift phase of which the most striking are those towards the Velika Morava trough (MAROVIĆ et al., 2007, see Figs. 17 and 21). It was built mostly from pre-Neogene, Jurassic-Cretaceous sediments (sometimes broken up by Upper Cretaceous and Tertiary volcanites), in the eastern belt of ultramafites (serpentinite, peridotite and dunites), and on the edge of Miocene deposits. All through the Neogene, the Avala horst shows different activity. In the early Miocene, it represented the unified horst structure including the Torlak and Kosmaj highs. It was an area of denudation, but in some parts, e.g. in the marginal horst zones and its local troughs-bays, deposition took place. During the late Middle Miocene (Sarmatian) the Avala horst separated from the Torlak horst by an E-NE to W-SW fault system and their uplift started as individual blocks. Generally, this trend of uplift has continued to recent time (MAROVIĆ et al., 2007).

\section{CONCLUSIONS}

Based on all the obtained results as well as their interpretation, the following conclusions concerning the Mio-Pliocene geodynamics and its consequences can be drawn.

In the studied area of Mt. Avala, the Torlak horst and Beli Potok trough are the most important geological block structures. They exhibit significant vertical displacements along the Rakovica fault of up to $200 \mathrm{~m}$. For example, in the borehole KGK-14, below the "Pontian" deposits there are Pannonian marls at absolute altitudes below 100 metres. However, only a few hundred metres away towards the northeast, at the foot of Torlak Hill, the same Pannonian marls are found at the surface at an altitude of about 210 metres. At the same time, at the top of Torlak Hill, Badenian sediments are present on the surface at an altitude of around
336 metres. They documented a well-known Paratethys marine transgression as one of the most important geological events during the Middle Miocene.

The field observations have confirmed that the Rakovica fault was tectonically active within the Pannonian and that the sedimentation in the Beli Potok trough occurred between the Late Pannonian to the "Late Pontian" (sensu STEVANOVIĆ). Besides, the occurrence of the large clastites and boulders near the Rakovica fault is related to their formation during the Late Miocene and Pliocene (and probably in the early Pleistocene).

As a result of vertical tectonic movements along the block structures, a complex hilly relief with Torlak Hill and a valley in the area of the Beli Potok was formed.

\section{ACKNOWLEDGMENT}

The authors wish to thank the Ministry of Education and Science, Republic of Serbia for supporting this study (Project no. 176015). We express thanks to Prof. M. TOLJIĆ (Belgrade University) for the helpful discussion regarding the structural features of the research area. Special gratitude goes to the reviewers for their constructive comments and suggestions that greatly improved an earlier version of the manuscript.

\section{REFERENCES}

ANDJELKOVIĆ, M. \& ANDJELKOVIĆ, J. (1996): Tektonsko - paleogeografsko - stratigrafski ciklusi u tercijaru Srbije [Tertiary Tectonic-Palaeogeographic-Stratigraphic Cycles of Serbia - in Serbian and English].- Ann. Geol. Pennins. Balk., $60 / 1,1-21$.

BADA, G., HORVATH, F., GERNER, P. \& FEJES, I. (1999): Review of the present-day geodynamics of the Pannonian basin: progress and problems.- Journal of Geodynamics, 27, 501-527. doi: 10.1016/S0264-3707(98)00013-1

BADA, G., HORVÁTH, F., DÖVÉNYI, P., SZAFIÁN, P., WINDHOFFER, G. \& CLOETINGH, S. (2007): Present-day stress field and tectonic inversion in the Pannonian basin.- Global and Planetary Change, 58, 165-180. doi: 10.1016/j.gloplacha.2007.01.007

BALÁZS, A., MATENCO, L., MAGYAR, I., HORVÁTH, F. \& CLOETINGH, S. (2016): The link between tectonics and sedimentation in back-arc basins: new genetic constraints from the analysis of the Pannonian Basin.- Tectonics, 35, 1526-1559. doi: 10.1002/2015TC004109

BALÁZS, A., BUROV, E., MATENCO, L., VOGT, K., FRANCOIS, T. \& CLOETINGH, S. (2017): Symmetry during the syn- and post-rift evolution of extensional back-arc basins: the role of inherited orogenic structures.- Earth Planet. Sci. Lett., 462, 86-98. doi: 10.1016/j.epsl.2017.01.015

ĆORIĆ, S., PAVELIĆ, D., ROGL, F., MANDIC, O., VRABAC, S., AVANIĆ, R., JERKOVIĆ, L. \& VRANJKOVIĆ, A. (2009): Revised Middle Miocene datum for initial marine flooding of North Croatian Basins (Pannonian Basin System, Central Paratethys).- Geologia Croatica, 62/1, 31-43. doi: 10.4154/GC.2009.03

DIMITRIJEVIĆ, M.D. (1997): Geology of Yugoslavia, 2nd edition.- Geoinstitute, Belgrade, $250 \mathrm{p}$

DJOKOVIĆ, I. \& MAROVIĆ, M. (1990): Rupturni sklop šireg područja Avale i Ljute strane (severna Šumadija). [Rupture setting of the broader area of the Avala and Ljuta strana (northern Šumadija) - in Serbian]. - XII Congress of geologists of Yugoslavia, Ohrid, vol. 5, 46-54.

DOLIĆ, D. (1997): Jezerski miocen kod Beograda [Lake Miocene near Belgrade - in Serbian and English].-Ann. Geol. Pennins. Balk., 61/2, 15-49.

DOLIĆ, D. (1998): The relationship of Paratethyan and Miocene lake deposits of Serbia. Proceedings of XIII Congress of Geologists of Yugoslavia, v. 2, p. 373-382.

DOMBRÁDI, E. (2012): Deformation of the Pannonian lithosphere and related tectonic topography: a depth-to-surface analysis.- Utrecht studies in earth sciences, 19, $1-176$.

EREMIJA, M. (1977a): Miocen u oblasti ekshumiranog mezozojsko-serpentinskog paleoreljefa, od Rakovice do Ripnja [Miocene in the exhumed Mesozoic-serpentine area of palaeorelief, from Rakovica to Ripanj - in Serbian].- In: PETKOVIĆ, K. (eds.): Géologie de le Serbie. Stratigraphie, II/3, 145-154.

EREMIJA, M. (1977b): Pliocen belopotočke rov-sinklinale [Pliocene of the Beli Potok trench-syncline - in Serbian].- In: PETKOVIĆ, K. (eds.): Géologie de le Serbie. Stratigraphie, II/3, 178-181.

EREMIJA, M. (1987): Badenski kat [Badenian - in Serbian].- In: ANĐELKOVIĆ, M. (eds.): La Géologie des Environs de Belgrade I, Géologie et Géodinamique, $151-172$. 
EREMIJA, M. (1989): Panonski kat [Pannonian - in Serbian, with an English summary].- In: ANĐELKOVIĆ, M. (eds.): Geology of the general Belgrade area. Vol.IV, Paleogeography. University of Belgrade, Belgrade, 244-259.

FODOR, L., BADA, G., CSILLAG, G., HORVÁTH, E., RUSZKICZAY-RÜDIGER, Z., PALOTÁS, K., SÍKHEGYI, F., TIMÁR, G., CLOETINGH, S. \& HORVÁTH, F. (2005): An outline of neotectonic structures and morphotectonics of the western and central Pannonian Basin.- Tectonophysics, 410, 15-41. doi: 10.1016/j.tecto.2005.06.008

GANIĆ, M., KNEŽEVIĆ, S., RUNDIĆ, LJ., MILUTINOVIĆ, A. \& GANIĆ, A. (2011): Neogene Geodynamics in the light of 3-D visualisation - an example along the Sava river (Belgrade).- In: BANJAC, N. (eds.): 17. MAEGS, Book of Proceed., $157-158$.

GANIĆ, M., RADOVIĆ, P., RUNDIĆ, LJ., BRADIĆ, K. \& KNEŽEVIĆ, S. (2016): Traces of Drilling Predation in The Upper Badenian (Middle Miocene) Molluscs from The Rakovica Stream (Belgrade).- Geologia Croatica, 69/2, 173-180. doi: 10.4154/GC.2016.14

HARZHAUSER, M. \& PILLER, W.E. (2007): Benchmark data of a changing sea - palaeogeography, palaeobiogeography and events in the Central Paratethys during the Miocene.- Palaeogeogr. Palaeoclimatol. Palaeoecol. 253, 8-31. doi: 10.1016/j.palaeo.2007.03.031

HARZHAUSER, M. \& MANDIC, O. (2008): Neogene lake systems of Central and South-Eastern Europe: faunal diversity, gradients and interrelations.- Palaeogeogr. Palaeoclimatol. Palaeoecol., 260, 417-434. doi: 10.1016/j.palaeo.2007.12.013

HORVÁTH, F. (1984): Neotectonics of the Pannonian basin and the surrounding mountain belts: Alps, Carpathians and Dinarides.-Annal. Geophys., 2, 147-154.

HORVÁTH, F., BADA, G., SZAFIÁN, P., TARI, G., ÁDÁM, A. \& CLOETINGH, S. (2006): Formation and deformation of the Pannonian Basin: constraints from observational data.- In: GEE, D.G. \& STEPHENSON, R. (eds.): European Lithosphere dynamics, Geological Society London Memoir, 32, 191-206. doi: 10.1144/ GSL.MEM.2006.032.01.11

HORVÁTH, F., MUSITZ, B., BALÁZS, A., VÉGH, A., UHRIN, A., NÁDOR, A., KOROKNAI, B., PAP, N., TÓTH, T. \& WÓRUM, G. (2015): Evolution of the Pannonian basin and its geothermal resources.- Geothermics, 53, 328-352. doi: 10.1016/j.geothermics.2014.07.009

IVKOVIĆ, A., VUKOVIĆ, A., NIKOLIC, J., KOVAČEVIĆ, D., PALAVESTRIĆ, LJ., PETROVIĆ, LJ., JOVANOVIĆ, O., TRIFUNOVIĆ, I. \& SEBINOVIĆ, LJ. (1966): Osnovna geološka karta SFRJ 1:100000, List Pančevo L34-114 [Basic Geological Map of SFRY 1:100000, Pančevo sheet - in Serbian].- Geološki zavod, Beograd, Savezni geološki zavod, Beograd.

KNEŽEVIĆ, S. (1989): Prinove iz ponta belopotočkog rova [New specimens from the Pontian of Beli Potok trough - in Serbian, with an English summary].-Ann. Geol. Pennins. Balk., 53, 373-384.

KNEŽEVIĆ, S. (1990): Prilog poznavanju neogenih sedimenata okoline Beograda (stratigrafski prikaz bušotine KGK-16 kod Vrčina [A contribution to the study of Neogene sediments in Beograd area (stratigraphic column of hole KGK-16 at Vrčin) - in Serbian, with an English summary].-Ann. Geol. Pennins. Balk., 54, 373-384.

KNEŽEVIĆ, S. \& ŠUMAR, M. (1994): Prilog poznavanju geologije grada Beograda [A contribution to the study of Belgrade local geology - in Serbian, with an English summary].-Ann. Geol. Pennins. Balk., 58/2, 73-81.

KNEŽEVIĆ, S., SPAJIĆ, O., PAVLOVIĆ, M., ERCEGOVAC, M. \& PETROVIĆ, M. (1994): Stratigrafska proucavanja tercijarnih naslaga u busotini G-1 u Grockoj [Stratigraphy of Tertiary Deposits in hole G-1 at Grocka - in Serbian, with an English summary].-Ann. Geol. Pennins. Balk., 58/2, 39-49.

KOVÁCS, G., FODOR, L., KÖVÉR, S., MOLNÁR, G., RAÁB, D., TELBISZ, T. \& TIMÁR, G. (2015): Verification of Late Miocene to Quaternary structural control on landforms: a case study with comprehensive methodology from a low hilly area (western Pannonian Basin).- Austrian Journal of Earth Sciences, 108/2, 82-104. doi: 10.17738/ajes.2015.0015

KOVAČIĆ, M., HORVAT, M., PIKIJA, M. \& SLOVENEC, DA. (2011): Composition and provenance of Neogene sedimentary rocks of Dilj gora Mt. (south Pannonian Basin, Croatia).- Geologia Croatica, 64/2, 121-132. doi: 10.4154/GC.2011.10

KRSTIĆ, N. (1972): Genus Candona (Ostracoda) from Congeria beds of southern Pannonian Basin.- Monographs, Vol. CDL, 39, SANU, Belgrade, 1-146.

KRSTIĆ, N. (1973): Biostratigraphy of the Congerian beds in the Belgrade region on the basis of Ostracoda.- Monographs, Vol. 4, Inst. Geol. Min. Expl. Investig. Nuclear Miner. Raw Mater., Belgrade, 1-158.

KRSTIĆ, N. (1985): Ostracoden im Pannonien der Umbegung von Belgrad.- In: PAPP, A. et al. (eds.): Chronostratigraphie und Neostratotypen, Miozän M6, Pannonien. Akadémiai Kiadó, 103-143.

KRSTIĆ, N., SAVIĆ, LJ. \& JOVANOVIĆ, G. (2012): The Neogene Lakes on the Balkan Land.-Ann. Geol. Pennins. Balk., 73, 37-60. doi: 10.2298/GABP1273037K

LASKAREV, V., PETKOVIĆ, V. \& LUKOVIĆ, M. (1931): Geološka karta okoline Beograda, 1: 25,000 [Geological Map of the Belgrade vicinity - in Serbian].- Geol. Inst. Kralj. Jugoslav., Beograd.
LUKOVIĆ, M. (1922): Facije drugog mediteranskog kata u okolini Beograda [Second Mediterranean facies from the Belgrade surroundings - in Serbian].- Ann. Geol. Pennins. Balk., 7/1, 22-41.

MAGYAR, I. \& GEARY, D.H. (2012): Biostratigraphy in a Late Neogene Caspian-Type Lacustrine Basin: Lake Pannon, Hungary.-AAPG Memoir, 95, 1-10.

MAGYAR, I., GEARY, D.H. \& MÜLLER, P. (1999): Palaeogeographic evolution of the Late Miocene Lake Pannon in Central Europe.- Palaeogeogr. Palaeoclimatol. Palaeoecol, 147, 151-167.

MAGYAR, I., RADIVOJEVIĆ, D., SZTANO, O., SYNAK, R., UJSZASZI, K. \& POCSIK, M. (2013): Progradation of the paleo-Danube shelf margin across the Pannonian Basin during the Late Miocene and Early Pliocene.- Global and Planetary Change, 103, 168-173. doi: 10.1016/j.gloplacha.2012.06.007

MANDIC, O., KUREČIĆ, T., NEUBAUER, T. \& HARZHAUSER, M. (2015): Stratigraphic and paleogeographic significance of lacustrine molluscs from the Pliocene Viviparus beds in central Croatia.- Geologia Croatica, 68/3, 179-207. doi: 10.4154/GC.2015.15

MAROVIĆ, M. \& KNEŽEVIĆ, S. (1985): Neotektonika jednog dela Šumadije i severozapadne Šumadije [Neotectonics of a part of Šumadija and northwestern Serbia - in Serbian, with an English summary].- Ann. Geol. Pennins. Balk., 49, 221-247.

MAROVIĆ, M., DJOKOVIĆ, I., KNEŽEVIĆ, S., RUNDIĆ, Lj., MITROVIĆ, S., ŠUMAR, M. \& TOLJIĆ, M. (1995): Principal geodynamic stages and paleogeographic changes in southeastern Peripannonian realm of Neogene and Quaternary.- Proc. XV Congress C.B.G.A., Geol. Soc. Greece, Athens, sp. publ., $4 / 1,69-73$

MAROVIĆ, M., DJOKOVIĆ, I., PEŠIĆ, L., RADOVANOVIĆ, S., TOLJIĆ, M. \& GERZINA, N. (2002): Neotectonics and seismicity of the southern margin of the Pannonian basin in Serbia.- EGU Special Publication, 277-295. doi: 10.5194/ smsps-3-277-2002

MAROVIĆ, M., TOLJIĆ, M., RUNDIĆ, Lj \& MILIVOJEVIĆ, J. (2007): Neoalpine tectonics of Serbia.- Ser. Monographs, Serbian Geological Society, Belgrade, 87 p.

MATENCO, L. \& RADIVOJEVIĆ, D. (2012): On the formation and evolution of the Pannonian Basin: Constraints derived from the structure of the junction area between the Carpathians and Dinarides.- Tectonics, 31, TC6007, 18-49. doi: 10.1029/2012TC003206

MATENCO, L., MUNTEANU, I., TER BORGH, M., STANICA, A., TILITA, M., LERICOLAIS, G., DINU, C. \& OAIE, G. (2016): The interplay between tectonics, sediment dynamics and gateways evolution in the Danube system from the Pannonian Basin to the western Black Sea.-Sci. Total Environ., 543, 807-827. doi: 10.1016/j.scitotenv.2015.10.081.

NEUBAUER, T., HARZHAUSER, M., KROH, A., GEORGOPOULOU, E. \& MANDIC, O. (2014): Replacement names and nomenclatural comments for problematic species-group names in Europe's Neogene freshwater Gastropoda. Part 2.Zookeys, 429, 13-46. doi: 10.3897/zookeys.429.7420

PAVELIĆ, D. \& KOVAČIĆ, M. (1999): Lower Miocene Alluvial Deposits of the Požeška Mt. (Pannonian Basin, Northern Croatia): Cycles, Megacycles and Tectonic Implications.- Geologia Croatica, 52/1, 67-76.

PAVELIĆ, D. \& KOVAČIĆ, M. (2018): Sedimentology and stratigraphy of the Neogene rift-type North Croatian Basin (Pannonian Basin System, Croatia).- A review, Marine and Petroleum Geology, 91, 455-469. doi: 10.1016/j.marp

PAVLOVIĆ, P.S. (1890): Mediteranska fauna u Rakovici [Mediterranean fauna of Rakovica - in Serbian].-Ann. Geol. Pennins. Balk., 2, 9-60.

PAVLOVIĆ, P.S. (1893): Prinove Geološkog zavoda [Noveltis from Geological Survey - in Serbian].- Ann. Geol. Pennins. Balk., 5/1, 212-223.

PAVLOVIĆ, P. (1931): Prilozi poznavanju tercijara u Srbiji (Pontiska fauna iz obala potoka Konopljište [Contributions to the knowledge of Tertiary in Serbia (Pontian fauna from the banks of the Konopljište stream) - in Serbian].-Ann. Geol. Pennins. Balk., 10/2, 104-113.

PETROVIĆ, M. (1995): Novi prilog poznavanju zona Ammonia beccarii i Prosononion granosum Beograda [A contribution to the study of Ammonia beccarii and Prosononion granosum zones in Belgrade - in Serbian, with an English summary].Ann. Geol. Pennins. Balk., 59/2, 61-68.

RADIVOJEVIĆ, D., RUNDIĆ, LJ. \& KNEŽEVIĆ, S. (2010): Geology of the Čoka structure in northern Banat (Central Paratethys, Serbia).- Geologica Carpathica, 61/4, $341-352$.

RADIVOJEVIĆ, D. \& RUNDIĆ, LJ. (2016): Synrift and postrift Miocene sediments of northern Banat, Serbia [Sinriftni i postriftni miocenski sedimenti severnog Banata u Srbiji - in English with Serbian abstract].- Underground Mining, 28, 39-60.

ROYDEN, L., HORVÁTH, F. \& RUMPLER, J. (1983): Evolution of the Pannonian Basin System. 1. Tectonics.- Tectonics, 2, 63-90. doi: 10.1029/TC002i001p00063

RUNDIĆ, LJ. \& KNEŽEVIĆ, S. (2017): The Miocene fossiliferous sites of the Avala Mt. (Belgrade area, Serbia) and their importance.- Bulletin of the Natural History Museum, 10, 29-41. doi: 10.5937/bnhmb1710029R

RUNDIĆ, LJ., GANIĆ, M., KNEŽEVIĆ, S. \& SOLIMAN, A. (2011): Upper Miocene Pannonian sediments from Belgrade (Serbia): new evidence and paleoenvironmental 
considerations.- Geologica Carpathica, 62/3, 267-278. doi: 10.2478/v10096-0110021-z

RUNDIĆ, LJ., KNEŽEVIĆ, S. \& RAKIJAŠ, M. (2013): Badenian marine transgression: new evidence from the Vrdnik coal basin (northern Serbia) [Srednje miocenska badenska transgresija: novi dokazi sa prostora Vrdničkog ugljenog basena (Fruška gora, Severna Srbija) - in English with an Serbian summary].-Ann. Geol. Pennins. Balk., 74, 9-23.

RUNDIĆ, LJ., KNEŽEVIĆ, S., GANIĆ, M. \& BRADIĆ, K. (2015): Novi podaci o stratigrafiji i tektonici Rakovičkog potoka (miocen okoline Beograda). [New data on stratigraphy and tectonics of the Rakovica stream, Miocene of the Belgrade vicinity - in Serbian and English].- In: SKOPLJAK, F. (eds.): 1st Congress of geologists of Bosnia \& Herzegovina, Tuzla October 21-23, 2015, Book of Abstracts, 48-49.

RUNDIĆ, LJ., VASIĆ, N., ŽIVOTIĆ, D., BECHTEL, A., KNEŽEVIĆ, S. \& CVETKOV, V. (2016): The Pliocene Paludina Lake of Pannonian Basin: new evidence from northern Serbia.- Annales Societatis Geologorum Poloniae, 86/2, 185-209. doi: 10.14241/asgp.2016.003

RUNDIĆ, LJ., GANIĆ, M., KNEŽEVIĆ, S. \& RADIVOJEVIĆ, D. (2017): Mio-Pliocene geodynamics and its stratigraphic consequences in the area of Avala Mt. (Belgrade, Serbia).- In: HORVAT, M. \& WACHA, L. (eds.): 7th Intern. Workshop on Neogene of Central and SE Europe, Abstracts Book, Velika, Croatia, 57-58

SANT, K., PALCU, D., MANDIC, O. \& KRIJGSMAN, W. (2017): Changing seas in the Early-Middle Miocene of Central Europe: a Mediterranean approach to Paratethyan stratigraphy.- Terra Nova, 29, 273-281. doi: 10.1111/ter.12273

SANT, K., MANDIC, O., RUNDIĆ, LJ., KUIPER, K. \& KRIJGSMAN, W. (2018): Age and evolution of the Serbian Lake System: integrated results from Middle Miocene Lake Popovac.- Newsletter on Stratigraphy, 51/1, 117-143. doi: 10.1127/ nos/2016/0360

SCHMID, S., BERNOULLI, D., FÜGENSCHUH, B., MATENCO, L., SCHEFER, S., SCHUSTER, R., TISCHLER, M. \& USTASZEWSKI, K. (2008): The AlpineCarpathian-Dinaridic orogenic system: correlation and evolution of tectonic units.Swiss Journal of Geosciences, 101, 139-183. doi: 10.1007/s00015-008-1247-3

SCHWARZHANS, W., BRADIĆ, K. \& RUNDIĆ, LJ. (2015): Fish-otoliths from the marine-brackish water transition from the Middle Miocene of the Belgrade area, Serbia.- Paläontologische Zeitschrift, 89/4, 815-837. doi: 10.1007/s12542-0150272-6

STEVANOVIĆ, P. (1951): Donji pliocen Srbije i susednih oblasti [Pontische stufe im Engeren sinne-obere Congerienschichten Serbiens und der angrenzenden gebiete - in Serbian, with an German summary].- Posebna izdanja SANU, CLXXXVII, Geol. Inst., 2, 361 p.

STEVANOVIĆ, P. (1970): Paleogeografsko-ekoloske prinove iz tortona okoline Beograda. [Neue palaeogeographisch-ökologische Beitrage zur Kenntnis des Tortons bei Belgrade - in Serbian, German summary].-Glas SANU, CCLXXVIII, odelj. prir.mat. nauka, 33, 1-26.

STEVANOVIĆ, P. (1985): Diskussion der Unterstufen Slavonien und Serbien.- In: PAPP, A., JÁMBOR, A. \& STEININGER, F.F. (eds.): Chronostratigraphie und Neostratotypen, Miozän der Zentralen Paratethys 7, Pannonien. Akadémiai Kiadó, Budapest, 82-85.
STEVANOVIĆ, P. (1990): Die pontische halbbrackische Molluscenfauna aus Serbien und Bosnien.- In: STEVANOVIĆ, P., NEVESSKAJA, L.A., MARINESCU, FL., SOKAČ, A. \& JÁMBOR, Á. (eds.): Chronostratigraphie und Neostratotypen: Neogen der Westlichen ("Zentrale") Paratethys 8. Pontien (1989). JAZU-SANU. Zagreb-Beograd, 462-536.

SUŠIĆ, Z., TOLJIĆ, M., BULATOVIĆ, V., NINKOV, T. \& STOJADINOVIĆ, U. (2015): Present-day Horizontal Mobility in the Serbian Part of the Pannonian Basin; Inferences from the Geometric Analysis of Deformations.-Acta Geophysica, 64/5, $1626-1654$.

SZTANÓ, O., SEBE, K., CSILLAG, G. \& MAGYAR, I. (2015): Turbidites as indicators of paleotopography, Upper Miocene Lake Pannon, Western Mecsek Mountains (Hungary).- Geologica Carpathica, 66/4, 331-344. doi: 10.1515/geoca-2015-0029

TARI, V. \& PAMIĆ, J. (1998): Geodynamic evolution of the northern Dinarides and the southern part of the Pannonian Basin.- Tectonophysics, 297, 269-281.

TER BORGH, M., VASILIEV, I., STOICA, M., KNEŽEVIĆ, S., MATENCO, L., KRIJGSMAN, W., RUNDIĆ, LJ. \& CLOETHING, S. (2013): The isolation of the Pannonian basin (Central Paratethys): new constraints from magneto- and biostratigraphy.- Global and Planetary Change, 103, 99-118. doi: 10.1016/j. gloplacha.2012.10.001

TER BORGH, M., RADIVOJEVIĆ, D. \& MATENCO, L. (2015): Constraining forcing factors and relative sea level fluctuations in semi-enclosed basins: the Late Neogene demise of Lake Pannon.- Basin Research, 6/27, 681-695. doi: 10.1111/bre.12094

TOLJIĆ, M. (1996): Neotektonski sklop Avale (Srbija). [The Neotectonic Pattern of Mount Avala (Serbia) - in Serbian and English].-Ann. Geol. Pennins. Balk., 60/1, $147-157$.

TOLJIĆ, M. (2006): Geološka građa Centralne Vardarske zone između Avale i Kosmaja [Geological setting of Central Vardar Zone between Avala and Kosmaj - in Serbian, with an English abstract].- Unpubl. PhD Thesis, Faculty of Mining and Geology, University of Belgrade, $162 \mathrm{p}$.

TOLJIĆ, M. (2016): Tectonic evolution of the European margin and Neotethys suture zone in the region of Belgrade (Northern Šumadija-Serbia).- Wseas Transactions on Environment and Development, 12, 268-277.

TOLJIĆ, M., NENADIĆ, D., STOJADINOVIĆ, U., GAUDÉNYI, T. \& BOGIĆEVIĆ, K. (2014): Quaternary tectonic and depositional evolution of eastern Srem (northwest Serbia) [Kvartarna tektonska i depoziciona evolucija istočnog Srema (severozapadna Srbija) - in English with an Serbian summary].- Ann. Geol. Pennins. Balk., 75, 43-57.

TOLJIĆ, M., MATENCO, L., STOJADINOVIC, U., WILLINGSHOFER, E. \& LJUBOVIĆ-OBRADOVIĆ, D. (2018): Understanding fossil fore-arc basins: Inferences from the Cretaceous Adria-Europe convergence in the NE Dinarides.Global and Planetary Change, 171, 167-184. doi: 10.1016/j.gloplacha.2018.01.018

VASKOVIĆ, N. \& MATOVIĆ, V. (1996): Tercijarne vulkanske stene Avale [The Tertiary Volcanic Rocks from Mt. Avala - in Serbian and English].- Ann. Geol. Pennins. Balk, 60/1, 391-414.

WIEDL, T., HARZHAUSER, M. \& PILLER, W.E. (2012): Facies and synsedimentary tectonics on a Badenian carbonate platform in the southern Vienna Basin (Austria, Central Paratethys).- Facies, 58, 523-548. doi: 10.1007/s10347-011-0290-0 